\title{
Estimates of ikaite export from sea ice to the underlying seawater in a sea ice-seawater mesocosm
}

\author{
Nicolas-Xavier Geilfus ${ }^{1,2}$, Ryan J. Galley ${ }^{1}$, Brent G. T. Else ${ }^{3}$, Karley Campbell ${ }^{1}$, Tim Papakyriakou ${ }^{1}$, Odile Crabeck $^{1}$, \\ Marcos Lemes $^{1}$, Bruno Delille ${ }^{4}$, and Søren Rysgaard ${ }^{1,2,5}$ \\ ${ }^{1}$ Centre for Earth Observation Science, University of Manitoba, Winnipeg, Canada \\ ${ }^{2}$ Arctic Research Centre, Aarhus University, Aarhus, Denmark \\ ${ }^{3}$ Department of Geography, University of Calgary, Calgary, Canada \\ ${ }^{4}$ Unité d'Océanographie Chimique, Université de Liège, Liège, Belgium \\ ${ }^{5}$ Greenland Climate Research Centre, Greenland Institute of Natural Resources, Nuuk, Greenland
}

Correspondence to: Nicolas-Xavier Geilfus (geilfusn@umanitoba.ca)

Received: 19 January 2016 - Published in The Cryosphere Discuss.: 11 February 2016

Revised: 12 August 2016 - Accepted: 15 August 2016 - Published: 21 September 2016

\begin{abstract}
The precipitation of ikaite and its fate within sea ice is still poorly understood. We quantify temporal inorganic carbon dynamics in sea ice from initial formation to its melt in a sea ice-seawater mesocosm pool from 11 to 29 January 2013. Based on measurements of total alkalinity (TA) and total dissolved inorganic carbon $\left(\mathrm{TCO}_{2}\right)$, the main processes affecting inorganic carbon dynamics within sea ice were ikaite precipitation and $\mathrm{CO}_{2}$ exchange with the atmosphere. In the underlying seawater, the dissolution of ikaite was the main process affecting inorganic carbon dynamics. Sea ice acted as an active layer, releasing $\mathrm{CO}_{2}$ to the atmosphere during the growth phase, taking up $\mathrm{CO}_{2}$ as it melted and exporting both ikaite and $\mathrm{TCO}_{2}$ into the underlying seawater during the whole experiment. Ikaite precipitation of up to $167 \mu \mathrm{mol} \mathrm{kg}{ }^{-1}$ within sea ice was estimated, while its export and dissolution into the underlying seawater was responsible for a TA increase of $64-66 \mu \mathrm{mol} \mathrm{kg}{ }^{-1}$ in the water column. The export of $\mathrm{TCO}_{2}$ from sea ice to the water column increased the underlying seawater $\mathrm{TCO}_{2}$ by $43.5 \mu \mathrm{mol} \mathrm{kg}{ }^{-1}$, suggesting that almost all of the $\mathrm{TCO}_{2}$ that left the sea ice was exported to the underlying seawater. The export of ikaite from the ice to the underlying seawater was associated with brine rejection during sea ice growth, increased vertical connectivity in sea ice due to the upward percolation of seawater and meltwater flushing during sea ice melt. Based on the change in TA in the water column around the onset of sea ice melt, more than half of the total ikaite precipitated in the ice during sea ice growth was still contained in the ice when the
\end{abstract}

sea ice began to melt. Ikaite crystal dissolution in the water column kept the seawater $p \mathrm{CO}_{2}$ undersaturated with respect to the atmosphere in spite of increased salinity, TA and $\mathrm{TCO}_{2}$ associated with sea ice growth. Results indicate that ikaite export from sea ice and its dissolution in the underlying seawater can potentially hamper the effect of oceanic acidification on the aragonite saturation state $\left(\Omega_{\text {aragonite }}\right)$ in fall and in winter in ice-covered areas, at the time when $\Omega_{\text {aragonite }}$ is smallest.

\section{Introduction}

Currently, each year, $7 \mathrm{Pg}$ anthropogenic carbon is released to the atmosphere, $29 \%$ of which is estimated to be taken up by the oceans through physical, chemical and biological processes (Sabine et al., 2004). The Arctic Ocean takes up -66 to $-199 \mathrm{TgC}$ year $^{-1}$, (where a negative value indicates an uptake of atmospheric $\mathrm{CO}_{2}$ ) contributing 5-14\% to the global ocean $\mathrm{CO}_{2}$ uptake (Bates and Mathis, 2009), primarily through primary production and surface cooling (MacGilchrist et al., 2014). However, polar ocean $\mathrm{CO}_{2}$ uptake estimates consider sea ice as an impermeable barrier, ignoring the potential role of ice-covered areas on gas exchange between the ocean and atmosphere. Recent studies have shown that sea-ice-covered areas participate in the variable sequestration of atmospheric $\mathrm{CO}_{2}$ into the mixed layer below the ice (e.g., Papakyriakou and Miller, 2011; Geil- 
fus et al., 2012, 2014, 2015; Nomura et al., 2013; Delille et al., 2014). Studies are required to elucidate the processes responsible for this as well as their magnitudes, both temporally and spatially.

The carbonate chemistry in sea ice and brine is spatially and temporally variable, which leads to complex $\mathrm{CO}_{2}$ dynamics with the potential to affect the air-sea $\mathrm{CO}_{2}$ flux (Parmentier et al., 2013). Release of $\mathrm{CO}_{2}$ from sea ice to the atmosphere has been reported during sea ice formation from open water (Geilfus et al., 2013a) and in winter (Miller et al., 2011; Fransson et al., 2013), while uptake of $\mathrm{CO}_{2}$ by sea ice from the atmosphere has been reported after sea ice melt onset (e.g., Semiletov et al., 2004; Nomura et al., 2010, 2013; Geilfus et al., 2012, 2014, 2015; Fransson et al., 2013). In combination, these works suggest that the temporal cycle of sea ice formation and melt affects atmospheric $\mathrm{CO}_{2}$ uptake by the ocean in variable ways. Sea ice may also act as an important control on the partial pressure of $\mathrm{CO}_{2}$ $\left(p \mathrm{CO}_{2}\right)$ in the sea surface through a sea ice pump (Rysgaard et al., 2007). During the earliest stages of sea ice formation, a small fraction of $\mathrm{CO}_{2}$-supersaturated brine is expelled upward onto the ice surface, promoting a release of $\mathrm{CO}_{2}$ to the atmosphere (Geilfus et al., 2013a). As sea ice forms and grows thicker, salts are partly rejected from the sea ice to the underlying seawater and partly trapped within the sea ice structure, concentrated in brine pockets, tubes and channels. As a result, the concentration of dissolved salts, including inorganic carbon, increases within the brine and promotes the precipitation of calcium carbonate crystals such as ikaite $\left(\mathrm{CaCO}_{3} \cdot 6 \mathrm{H}_{2} \mathrm{O}\right)$ (Marion, 2001). These crystals have been reported in both natural (Dieckmann et al., 2008; Nomura et al., 2013; Søgaard et al., 2013) and experimental sea ice (Geilfus et al., 2013b; Rysgaard et al., 2014) and have been suggested to be a key component of the carbonate system (Rysgaard et al., 2007; Fransson et al., 2013; Delille et al., 2014).

During ikaite precipitation within sea ice, total alkalinity (TA) in brine is reduced by 2 moles due to the reduction of bicarbonate $\left(\mathrm{HCO}_{3}^{-}\right)$while total dissolved inorganic carbon $\left(\mathrm{TCO}_{2}\right)$ in brine is only reduced by 1 mol (Reactions R1$\mathrm{R} 3)$ :

$$
\begin{aligned}
& \mathrm{Ca}^{2+}+2 \mathrm{HCO}_{3}^{-}+5 \mathrm{H}_{2} \mathrm{O} \rightleftharpoons \mathrm{CaCO}_{3} \cdot 6 \mathrm{H}_{2} \mathrm{O}+\mathrm{CO}_{2}, \\
& \mathrm{TCO}_{2}=\left[\mathrm{HCO}_{3}^{-}\right]+\left[\mathrm{CO}_{3}^{2-}\right]+\left[\mathrm{CO}_{2}\right], \\
& \mathrm{TA}=\left[\mathrm{HCO}_{3}^{-}\right]+2\left[\mathrm{CO}_{3}^{2-}\right]+\left[\mathrm{B}(\mathrm{OH})_{4}^{-}\right]+\left[\mathrm{OH}^{-}\right]-\left[\mathrm{H}^{+}\right] .
\end{aligned}
$$

The specific conditions leading to ikaite precipitation, as well as the fate of these precipitates in sea ice, are still not fully understood. Ikaite crystals may remain within the ice structure, while the $\mathrm{CO}_{2}$ formed during their precipitation is likely rejected with dense brine to the underlying seawater and sequestered below the mixed layer. During sea ice melt, the dissolution of these crystals triggered by increased ice temperatures and decreased bulk ice salinity will consume $\mathrm{CO}_{2}$ and drive a $\mathrm{CO}_{2}$ uptake from the atmosphere to the ice. Such a mechanism could be an effective sea ice pump of atmospheric $\mathrm{CO}_{2}$ (Delille et al., 2014). In addition, ikaite stored in the ice matrix could become a source of TA to the nearsurface ocean upon its subsequent dissolution during sea ice melt (Rysgaard et al., 2007, 2009).

The main air-sea fluxes of $\mathrm{CO}_{2}$ and $\mathrm{TCO}_{2}$ are driven by brine rejection to the underlying seawater and its contribution to intermediate and deep-water formation (Semiletov et al., 2004; Rysgaard et al., 2007, 2009; Fransson et al., 2013) or below sea ice in ice tank studies (e.g., Killawee et al., 1998; Papadimitriou et al., 2004). As sea ice thickens, reduced near-surface ice temperatures result in reduced brine volume content, increased brine salinity and increased solute concentration in the brine. In the spring-summer, as the ice temperature increases, sea ice brine volume increases and sea ice becomes vertically permeable to liquid (Golden et al., 2007), enhancing the potential $\mathrm{CO}_{2}$ exchange between the atmosphere, sea ice and ocean. Eventually internal ice melt promotes brine dilution, which decreases brine salinity, TA and $\mathrm{TCO}_{2}$, and leads to lower $p \mathrm{CO}_{2}$ in the brine. In addition, the dissolution of ikaite decreases brine $p \mathrm{CO}_{2}$ (Reaction R1) (Geilfus et al., 2012, 2015). These conditions all favor sea ice as a sink for atmospheric $\mathrm{CO}_{2}$ (Nomura et al., 2010, 2013; Geilfus et al., 2012, 2015). Melting sea ice stratifies surface seawater, leading to decreased TA, $\mathrm{TCO}_{2}$ and $p \mathrm{CO}_{2}$, in the sea surface, enhancing air-sea $\mathrm{CO}_{2}$ fluxes (Rysgaard et al., 2007, 2009).

Although we now have a basic understanding of the key mechanisms of carbon cycling in sea ice, significant unknowns remain. One of the major unknowns is the fate of ikaite, $\mathrm{TCO}_{2}$ and $\mathrm{CO}_{2}$ released from sea ice during winter. It is unclear what proportion of precipitated ikaite crystals in sea ice remains in the matrix to be released upon melt or what proportion is expelled with brine drainage during ice formation and growth. Examining the chemical signatures of the water column beneath sea ice may provide an indication of the importance of the different processes. However, the signal of carbon components released from 1 to $2 \mathrm{~m}$ of sea ice growth is difficult to detect in a water column several hundred meters deep.

In this study, we followed the evolution of the inorganic carbon dynamics within experimental sea ice from sea ice formation to melt in a sea ice-seawater mesocosm pool $\left(\sim 435 \mathrm{~m}^{3}\right)$ at the University of Manitoba, Winnipeg, Canada. The benefits of this type of environment are multiple. An artificial pool equipped with a movable bridge makes it possible to collect undisturbed samples from thin growing sea ice. We gain the ability to carefully track carbonate parameters in the ice, in the atmosphere and in the underlying seawater, while growing sea ice in a large volume of seawater, so that conditions closely mimic the natural system. During this experiment, we examined physical and chemical processes, in the absence of biology, responsible for changes in the inorganic carbon system of sea ice and the underlying 
seawater, and quantified fluxes of inorganic carbon between the atmosphere, sea ice and the water column. We also discuss that dissolution of ikaite crystals exported from sea ice in the underlying seawater can potentially hamper the effect of oceanic acidification on $\Omega_{\text {aragonite }}$.

\section{Site description, sampling and analysis}

The Sea-ice Environmental Research Facility (SERF) is an inground outdoor concrete pool, $18.3 \mathrm{~m} \times 9.1 \mathrm{~m}$ in surface area and $2.6 \mathrm{~m}$ deep, exposed to ambient temperatures, winds and solar radiation (by retracting its roof, Fig. 1). The weather conditions in the region are conducive to sea ice growth for several months every winter. Prior to the experiment, the pool is filled with artificial seawater (ASW) made by dissolving large quantities of various rock salts into local groundwater to mimic the major composition of natural seawater (see Rysgaard et al., 2014 for exact composition of the ASW). Sea ice is melted in the pool by circulating heated ethylene glycol through a closed-loop hose located at the bottom of the pool, allowing successive ice growth/melt experiments to be carried out during one winter. The experimental sea ice and brine exhibit similar physical and chemical properties to those observed in natural Arctic sea ice (Geilfus et al., 2013b; Hare et al., 2013). The experiment described herein was initiated from open water conditions on 11 January 2013 when the heater was turned off. Sea ice grew until 26 January when the heat was turned back on. The experiment ended on 30 January when the pool was $20 \%$ ice-free.

Four $375 \mathrm{~W}$ pumps were installed on the bottom of the pool near each of the corners to induce a consistent current. The pumps were configured to draw water from their base and then propel it outward parallel to the bottom of the pool. The pumps were oriented successively at right angles to one another, which created a counterclockwise circulation of 2$3 \mathrm{~cm} \mathrm{~s}^{-1}$ (Else et al., 2015).

Bulk ice and seawater temperatures were recorded by an automated type-T thermocouple array fixed vertically in the pool. Seawater salinity was measured continuously using Aanderaa CT sensors (model 4319) located at 30, 100, 175 and $245 \mathrm{~cm}$ depth. The in situ seawater $p \mathrm{CO}_{2}$ was measured every $5 \mathrm{~s}$ using a Contros HydroC (resolution $<1 \mu \mathrm{atm}$, accuracy $\pm 1 \%$ of the upper range value) located at $1.3 \mathrm{~m}$ depth.

Air temperature and relative humidity were measured using a Vaisala HMP45C probe at a meteorological station located $2 \mathrm{~m}$ above the sea ice surface. Solar irradiance was continuously recorded by an Eppley Precision Spectral Pyranometer (range of $0.285-2.8 \mu \mathrm{m}$ ) mounted $10 \mathrm{~m}$ above the sea ice surface. In addition, estimated photosynthetically active radiation (PAR) values at the ice bottom were recorded with Alec mkV/L PAR sensors throughout the study and ranged from 0 to $892 \mu \mathrm{mol}$ photons $\mathrm{m}^{-2} \mathrm{~s}^{-1}$.

Sea ice and seawater samples were obtained from a confined area located on the north side of the pool to minimize

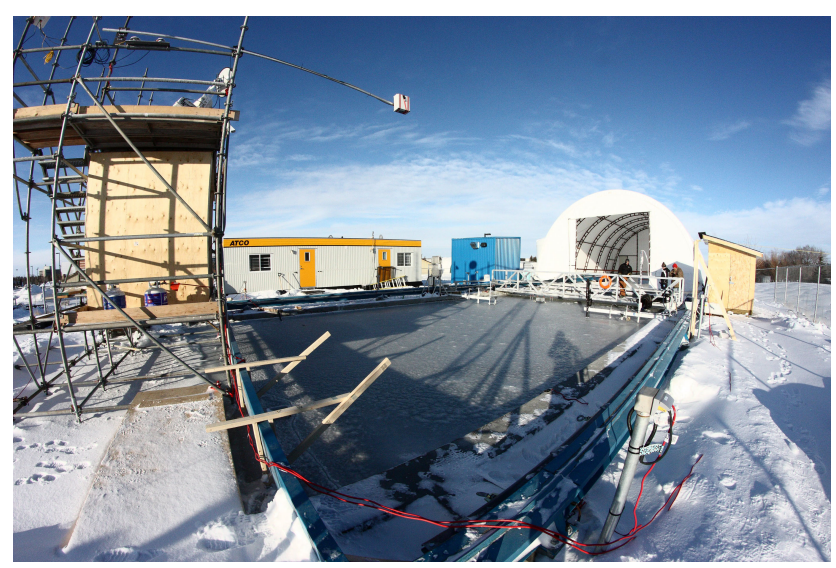

Figure 1. The Sea-ice Environmental Research Facility (University of Manitoba, Winnipeg, Canada) with thin sea ice covering the pond during the 2013 experiment. Photo: J. Sievers.

effects on other experiments (e.g., Else et al., 2015). Ice samples were collected using ceramic knives or a Kovacs Mark II coring system depending on the ice thickness. Sampling was performed from a movable bridge to avoid walking on the ice surface and to ensure only undisturbed sites were sampled. Ice cores were collected from one end of the pool (half meter away from the edge of the pool) and at least $20 \mathrm{~cm}$ away from previous cored sites. Ice cores were packed in clean plastic bags and kept frozen during the 20 min transport to a cold laboratory and processed within a few hours. Seawater was sampled for total alkalinity (TA) and total dissolved inorganic carbon $\left(\mathrm{TCO}_{2}\right)$ with a peristaltic pump (Cole Parmer Masterflex ${ }^{\circledR}$ Environment Sampler, equipped with PTFE tubing) through an ice core hole of the ice-water interface, at 1.25 and $2.5 \mathrm{~m}$ depth. Samples were stored in $12 \mathrm{~mL}$ gastight vials (Exetainer, Labco High Wycombe, United Kingdom) and poisoned with $12 \mu \mathrm{L}$ of saturated $\mathrm{HgCl}_{2}$ solution and stored in the dark at $4{ }^{\circ} \mathrm{C}$ until analyzed.

Air-ice $\mathrm{CO}_{2}$ fluxes were measured using a Li-Cor 8100103 chamber associated with a LI-8100A soil $\mathrm{CO}_{2}$ flux systems. The chamber was connected in a closed loop to the IRGA with an air pump rate of $3 \mathrm{~L} \mathrm{~min}^{-1}$. The measurement of $p \mathrm{CO}_{2}$ in the chamber was recorded every second over a $15 \mathrm{~min}$ period. The flux was computed from the slope of the linear regression of $p \mathrm{CO}_{2}$ against time $\left(r^{2}>0.99\right)$ according to Frankignoulle (1988), taking into account the volume of ice or snow enclosed within the chamber. The uncertainty of the flux computation due to the standard error on the regression slope was on average $\pm 3 \%$.

In the cold laboratory, sea ice cores were cut into $2 \mathrm{~cm}$ sections using a pre-cleaned stainless steel band saw. Each section was placed in a gas-tight laminated (Nylon, ethylene vinyl alcohol and polyethylene) plastic bag (Hansen et al., 2000) fitted with a gas-tight Tygon tube and a valve for sampling. The plastic bag was sealed immediately, and excess air was gently removed through the valve using a vac- 
uum pump. The bagged sea ice samples were then melted in the dark at $4{ }^{\circ} \mathrm{C}$ to minimize the dissolution of calcium carbonate precipitates (meltwater temperature never rose significantly above $0^{\circ} \mathrm{C}$ ). Once melted, the meltwater mixture and bubbles were transferred to gas-tight vials $(12 \mathrm{~mL} \mathrm{Ex}$ etainer, Labco High Wycombe, United Kingdom), poisoned with $12 \mu \mathrm{L}$ solution of saturated $\mathrm{HgCl}_{2}$ and stored in the dark at $4{ }^{\circ} \mathrm{C}$ until analyzed.

Bulk ice and seawater salinities were measured using a Thermo Orion 3-star with an Orion 013610MD conductivity cell, and values were converted to bulk salinity (Grasshoff et al., 1983). TA was determined by potentiometric titration (Haraldsson et al., 1997), while $\mathrm{TCO}_{2}$ was measured on a coulometer (Johnson et al., 1987). Routine analysis of Certified Reference Materials provided by A. G. Dickson, Scripps Institution of Oceanography, verified that $\mathrm{TA}$ and $\mathrm{TCO}_{2}$ were analyzed within \pm 3 and $\pm 2 \mu \mathrm{mol} \mathrm{kg}{ }^{-1}$, respectively. Brine volume was estimated from measurements of bulk salinity, temperature and density according to Cox and Weeks (1983) for temperatures below $-2{ }^{\circ} \mathrm{C}$ and according to Leppäranta and Manninen (1988) for ice temperatures within the range -2 to $0^{\circ} \mathrm{C}$.

Bulk ice samples for biological measurements were collected between 14 and 21 January. Filtered $(0.2 \mu \mathrm{m})$ SERF seawater (FSW) was added at a ratio of three parts FSW to one part ice and the samples were left to melt in the dark. Chl $a$ was determined on three occasions by filtering two aliquots of the melted ice sample onto GF/F filters (Whatman ${ }^{\circledR}$ brand) and extracting pigments in $10 \mathrm{~mL}$ of $90 \%$ acetone for $24 \mathrm{~h}$. Fluorescence was measured before and after the addition of $5 \% \mathrm{HCl}$ (with a Turner Designs fluorometer), and chl $a$ concentration was calculated following Parsons et al. (1984). Measurements of bacterial production were done four times during the biological sampling period by incubating $6-10 \mathrm{~mL}$ subsamples of the iceFSW solution with ${ }^{3} \mathrm{H}$-leucine (final concentration of $10 \mathrm{nM}$ ) for $3 \mathrm{~h}$ at $0^{\circ} \mathrm{C}$ in darkness (Kirchmann, 2001). Half of the samples were spiked with trichloroacetic acid (TCA, final concentration $5 \%$ ) as controls prior to the incubation, while the remaining active subsamples were fixed with TCA (final concentration $5 \%$ ) after incubation. Following the incubation, vials were placed in $80^{\circ} \mathrm{C}$ water for $15 \mathrm{~min}$ (Garneau et al., 2006) before filtration through $0.2 \mu$ m cellulose acetate membranes (Whatman ${ }^{\circledR}$ brand) and rinsing with $5 \%$ TCA and $95 \%$ ethanol. Filters were dried and dissolved in scintillation vials by adding $1 \mathrm{~mL}$ ethyl acetate, and radioactivity was measured on a liquid scintillation counter after an extraction period of $24 \mathrm{~h}$. Bacterial production was calculated using the equations of Kirchman (1993) and a conversion factor of $1.5 \mathrm{~kg} \mathrm{C} \mathrm{mol}^{-1}$ (Ducklow et al., 2003).

\section{Results}

\subsection{Sea ice and seawater physical conditions}

Sea ice was grown in the pool from open water on 13 January 2013 and reached a maximum thickness of $24 \mathrm{~cm}$ on $26 \mathrm{Jan}-$ uary at which point the heat at the base of the pool was turned on. On 30 January the experiment ended with the pool $20 \%$ ice-free. Three main snowfall events occurred during the experiment. The first, from 14 to 15 January, covered the sea ice surface with $1 \mathrm{~cm}$ of snow. The second, from 18 to $23 \mathrm{Jan}-$ uary, deposited 6-9 $\mathrm{cm}$ of snow over the entire pool. On the morning of 23 January, the snow was manually cleared off the ice surface to investigate the insulating effect of the snow on the ice temperature and ikaite precipitation (Rysgaard et al., 2014). Finally, from noon on 24 to 27 January, $8 \mathrm{~cm}$ of snow covered the entire pool until the end of the experiment on 30 January.

The air temperature at the beginning of the experiment ranged from -2 to $-26^{\circ} \mathrm{C}$, which initiated rapid sea ice growth to $15 \mathrm{~cm}$ until 18 January (Fig. 2). During this initial sea ice growth, the sea ice was attached to the side of the pool, resulting in the development of a hydrostatic pressure head that caused percolation of seawater at the freezing point upwards through the sea ice volume as the sea ice grew downwards. This resulted in repeated events of increased sea ice temperature from the bottom to the surface observed between 15 and 18 January (Fig. 2). Subsequently, the ice was cut using an ice saw around the perimeter, allowing the ice to float, and a pressure release valve was installed to prevent such events (Rysgaard et al., 2014). During this period, the ice temperature oscillated between relatively warm $\left(\sim-3{ }^{\circ} \mathrm{C}\right)$ and cold $\left(\sim-7^{\circ} \mathrm{C}\right)$ phases. Brine volume content (0.047) was low in the middle part of the ice cover, close to the permeability threshold of 0.05 as suggested by Golden et al. (2007). The bulk ice salinity profiles were typically C-shaped, with values ranging from 6 to 23 (Fig. 2). The underlying seawater salinity increased rapidly due to sea ice growth. From 18 to 23 January, the $9 \mathrm{~cm}$ snow cover insulated the ice cover from the cold atmosphere (Rysgaard et al., 2014), resulting in a fairly constant ice thickness, nearly no change in ice temperature and salinity, a brine volume content above the permeability threshold and a small increase in the underlying seawater salinity. Once the ice surface was cleared of snow on the morning of 23 January, the ice temperature decreased throughout the entire ice thickness and the ice surface salinity increased. The sea ice volume cooled from the top downwards, and the brine volume content decreased below the permeability threshold on 23 January and rapid sea ice growth rapidly increased the seawater salinity. Shortly after the snow clearing, the last snowfall event covered the ice surface with $8 \mathrm{~cm}$ of snow, reducing the effect of the cold atmosphere on the ice cover. On 26 January, the heater was activated to initiate sea ice melt. Sea ice temperatures increased and became isothermal around $-2{ }^{\circ} \mathrm{C}$, while 
(a)

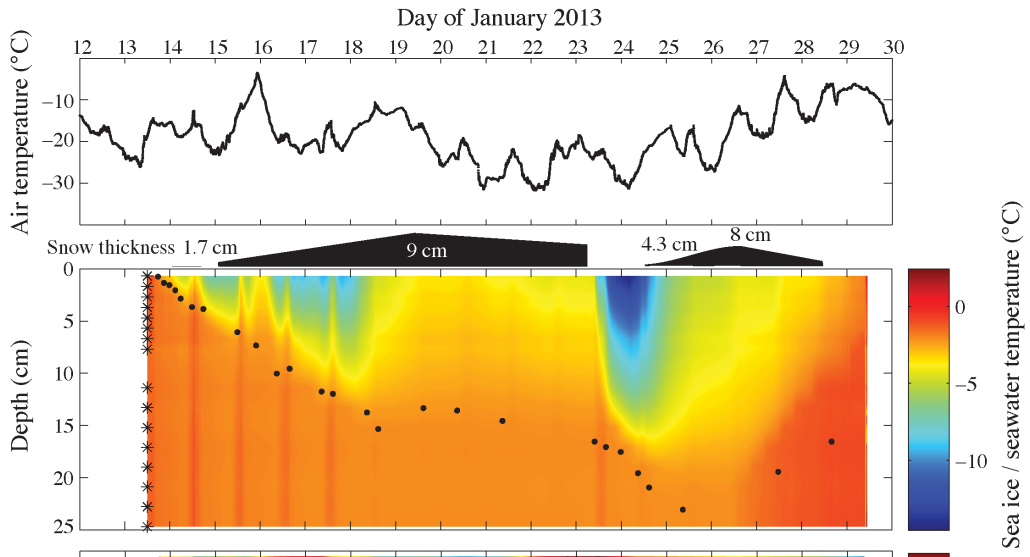

(c)

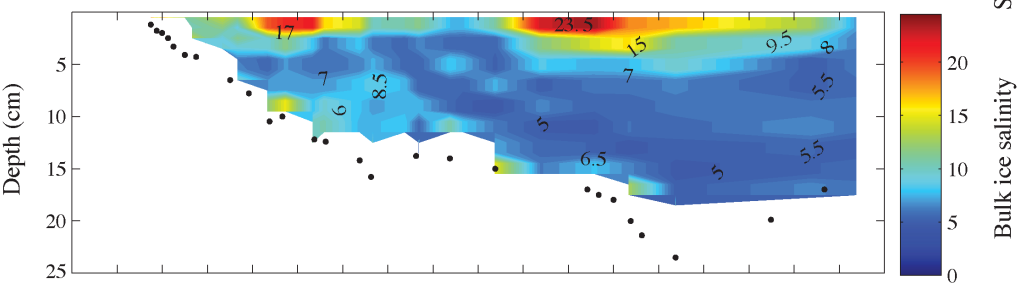

(d)

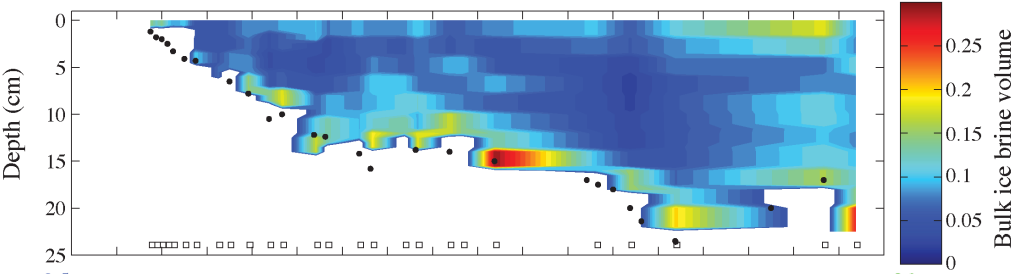

(e)

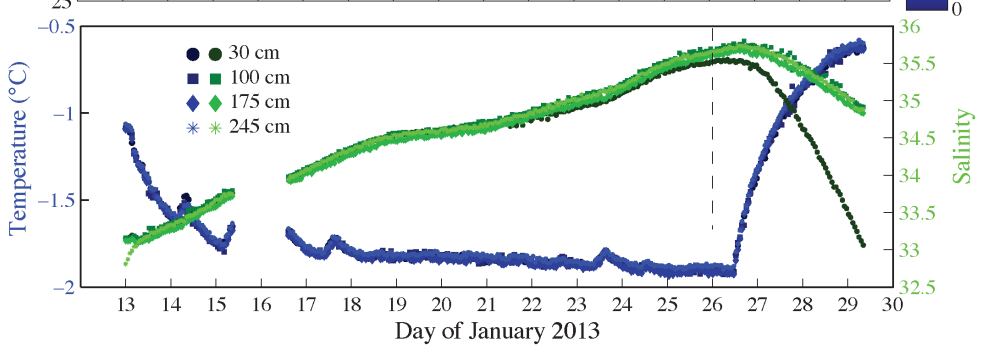

Figure 2. Evolution of (a) air temperature $\left({ }^{\circ} \mathrm{C}\right)$ at $2 \mathrm{~m}$ height, (b) snow thickness (black shaded areas) and sea ice/seawater temperature $\left({ }^{\circ} \mathrm{C}\right)$, (c) bulk ice salinity, (d) brine volume content within sea ice and (e) seawater temperature (blue) and salinity (green). Measurements were performed at 30,100, 175 and $245 \mathrm{~cm}$ water depths. The darker the color is, the closer to the surface. In panels (b-d) sea ice thickness is illustrated by black dots. Stars on panel (b) represent the depth at which the temperature profiles are derived from. Open squares in the lower part of (d) mark the sampling times. The dashed line on panel (e) indicates when the heat at the bottom of the pool was turned back on.

the bulk ice salinity decreased and the brine volume content increased up to 0.13 . The sea ice melt decreased the seawater salinity. The pool was well mixed during the whole growth phase with similar salinity and temperature observed at the four depths. However, once the heat was turned on, the pool become stratified with respect to salinity changes, as the salinity at $30 \mathrm{~cm}$ depth started to diverge from the deeper depths (Fig. 2).

\subsection{Carbonate system}

TA and $\mathrm{TCO}_{2}$ in seawater, noted as $\mathrm{TA}_{(\mathrm{sw})}$ and $\mathrm{TCO}_{2(\mathrm{sw})}$, were sampled at the sea ice-seawater interface, at 1.25 and
$2.5 \mathrm{~m}$ depth. An analysis of variance (ANOVA) test over the three depths revealed that the means are not statistically different $(p<0.01)$, so we consider the average concentration of the three depths in the following analysis. During sea ice growth, $\mathrm{TA}_{(\mathrm{sw})}$ increased from 2449 to $2644 \mu \mathrm{mol} \mathrm{kg}{ }^{-1}$ (black line, Fig. 3a), while $\mathrm{TCO}_{2(\mathrm{sw})}$ increased from 2347 to $2516 \mu \mathrm{mol} \mathrm{kg}^{-1}$ (black line, Fig. 3b). Once the ice started to melt, $\mathrm{TA}_{(\mathrm{sw})}$ decreased to $2607 \mu \mathrm{mol} \mathrm{kg}{ }^{-1}$, and $\mathrm{TCO}_{2(\mathrm{sw})}$ decreased to $2461 \mu \mathrm{mol} \mathrm{kg}^{-1}$. As the experiment stopped before the ice was completely melted in the tank, both the seawater salinity and $\mathrm{TA}_{(\mathrm{sw})}$ do not reach their initial values by the end of the experiment (Table 1, Figs. 2, 3). To discard the effect of salinity changes, we normalized $\mathrm{TA}_{(\mathrm{sw})}$ 
Table 1. Seawater conditions on 11 January, before any sea ice formation $(t=0)$, on 25 January, just before the heat was turned back on and on 29 January, at the end of the experiment. Note that seawater salinity and $\mathrm{TA}_{(\mathrm{sw})}$ do not reach the initial seawater values as sea ice was still present at the end of the experiment.

\begin{tabular}{lcccccc}
\hline Date & Temperature & Salinity & $\mathrm{TA}_{(\mathrm{sw})}$ & $\mathrm{nTA}_{(\mathrm{sw})}$ & $\mathrm{TCO}_{2(\mathrm{sw})}$ & $\mathrm{nTCO}_{2(\mathrm{sw})}$ \\
\cline { 4 - 6 } & $\left({ }^{\circ} \mathrm{C}\right)$ & & \multicolumn{4}{c}{$\left(\mu \mathrm{mol} \mathrm{kg}^{-1}\right)$} \\
\hline 11 January & -1.4 & 33.5 & 2453 & 2416 & 2341 & 2306 \\
25 January & -1.9 & 35.5 & 2659 & 2471 & 2524 & 2346 \\
29 January & -0.6 & 34.4 & 2607 & 2500 & 2461 & 2361 \\
\hline
\end{tabular}

(a)

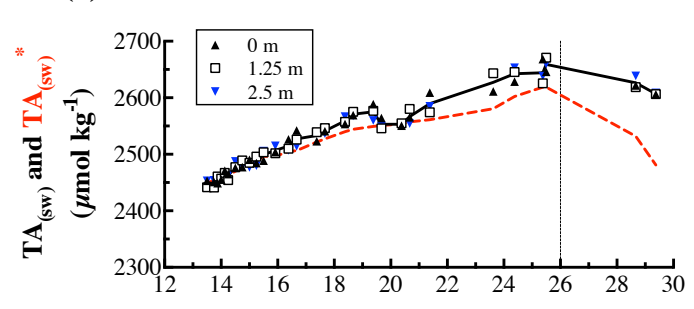

(c)

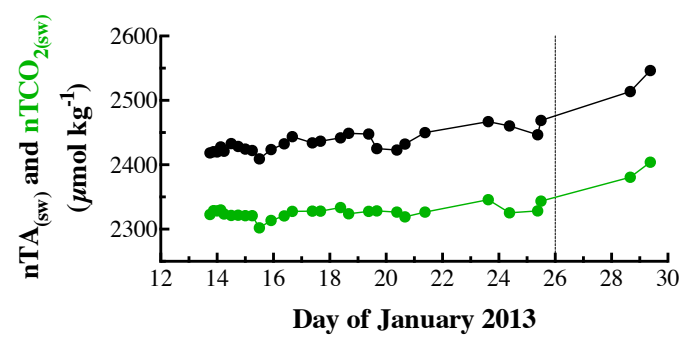

(b)

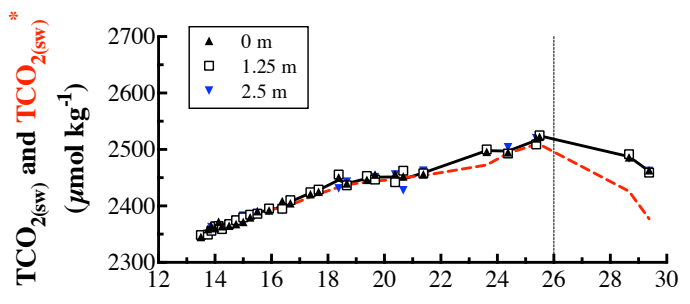

(d)

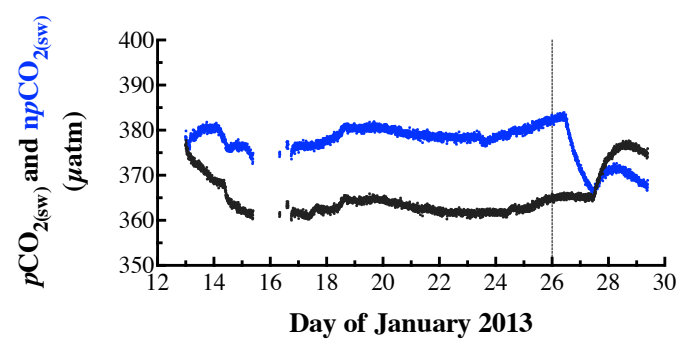

Figure 3. Evolution of (a) $\mathrm{TA}_{(\mathrm{sw})}$ and $\mathrm{TA}_{(\mathrm{sw})}^{*}\left(\mu \mathrm{mol} \mathrm{kg}{ }^{-1}\right)$, (b) $\mathrm{TCO}_{2(\mathrm{sw})}$ and $\mathrm{TCO}_{2(\mathrm{sw})}^{*}\left(\mu \mathrm{mol} \mathrm{kg}{ }^{-1}\right)$, (c) nTA $(\mathrm{sw})(\mathrm{black})$ and nTCO $2(\mathrm{sw})$ (green) $\left(\mu \mathrm{mol} \mathrm{kg}{ }^{-1}\right)$ and $(\mathbf{d})$ the seawater $p \mathrm{CO}_{2}$ ( $\mu$ atm) measured in situ (black) and corrected to a constant temperature of $-1{ }^{\circ} \mathrm{C}(\mathrm{blue})$. In panels (a) and (b) the black line is the average over the three depths, while the dotted red line is the expected concentrations according to the variation of salinity observed and calculated from the mean values of the three depths $\left(\mathrm{TA}_{(\mathrm{sw})}^{*}\right.$ and $\mathrm{TCO}_{2(\mathrm{sw})}^{*}$, respectively). The vertical black dotted line on 26 January marks when the heat was turned back on.

and $\mathrm{TCO}_{2(\mathrm{sw})}$ to a salinity of 33 (noted as $\mathrm{nTA}_{(\mathrm{sw})}$ and $\mathrm{nTCO}_{2(\mathrm{sw})}$ ) according to Reactions (R4) and (R5):

$\operatorname{nTA}_{(\text {sample })}=\frac{\mathrm{TA}_{(\text {sample })}}{S_{(\text {sample) } t}} \times 33$,
$\operatorname{nTCO}_{2 \text { (sample) } t}=\frac{\mathrm{TCO}_{2 \text { (sample) } t}}{S_{(\text {sample })}} \times 33$,

where $t$ is the time of the sampling and $S$ the salinity of the sample (seawater or sea ice). During ice growth, $\mathrm{nTA}_{(\mathrm{sw})}$ and $\mathrm{nTCO}_{2(\mathrm{sw})}$ increased slightly to 2446 and $2328 \mu \mathrm{mol} \mathrm{kg}{ }^{-1}$, respectively (Fig. 3c). However, once the ice started to melt, $\mathrm{nTA}_{(\mathrm{sw})}$ increased to $2546 \mu \mathrm{mol} \mathrm{kg}{ }^{-1}$, and $\mathrm{nTCO}_{2(\mathrm{sw})}$ increased to $2404 \mu \mathrm{mol} \mathrm{kg}^{-1}$.

The in situ $p \mathrm{CO}_{2}$ of the underlying seawater $\left(p \mathrm{CO}_{2(\mathrm{sw})}\right)$ decreased from 377 to $360 \mu \mathrm{atm}$ as the seawater temperature in the pool decreased to the freezing point. The $p \mathrm{CO}_{2(\mathrm{sw})}$ then oscillated from 360 to $365 \mu$ atm during sea ice growth. One day after the heater was turned on, the $p \mathrm{CO}_{2(\mathrm{sw})}$ increased to a similar concentration as at the beginning of the experiment, before decreasing to $373 \mu \mathrm{atm}$ by the end of the experiment (Fig. 3d).

Within bulk sea ice, $\mathrm{TA}_{(\text {ice) }}$ ranged from 300 to $1907 \mu \mathrm{mol} \mathrm{kg}^{-1}$, while $\mathrm{TCO}_{2 \text { (ice) }}$ ranged from 237 to $1685 \mu \mathrm{mol} \mathrm{kg}{ }^{-1}$. Both $\mathrm{TA}_{(\text {ice })}$ and $\mathrm{TCO}_{2 \text { (ice) }}$ exhibited Cshaped profiles with higher concentrations at the surface and bottom layers of the ice cover (Fig. 4). The concentration of $\mathrm{TA}_{\text {(ice) }}$ (average of $476 \mu \mathrm{mol} \mathrm{kg}^{-1}$ ) and $\mathrm{TCO}_{2 \text { (ice) }}$ (average of $408 \mu \mathrm{mol} \mathrm{kg}^{-1}$ ) did not show significant variability during our survey, except at the surface of the ice. A first maximum was observed on 17 January with a concentration of $1907 \mu \mathrm{mol} \mathrm{kg}^{-1}$ for $\mathrm{TA}_{(\text {ice) }}$ and $1685 \mu \mathrm{mol} \mathrm{kg}^{-1}$ for $\mathrm{TCO}_{2 \text { (ice) }}$. A second maximum was observed on 23 January with a concentration of $1433 \mu \mathrm{mol} \mathrm{kg}^{-1}$ for $\mathrm{TA}_{(\text {ice) }}$ and 
(a) $\mathrm{TA}\left(\mu \mathrm{mol} \mathrm{kg}{ }^{-1}\right)$

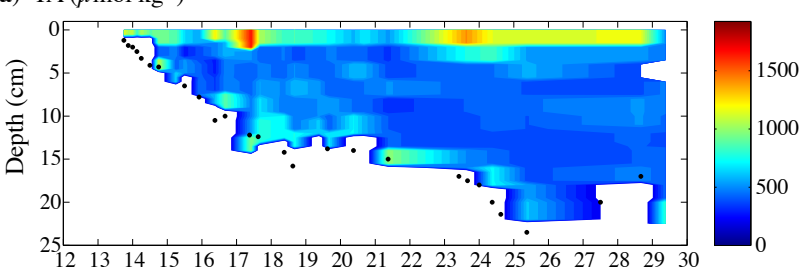

(b) $\left.\mathrm{TCO}_{2}(\mu \mathrm{mol} \mathrm{kg})^{-1}\right)$

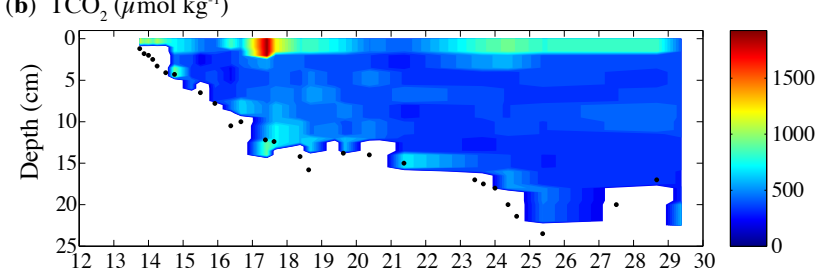

(c) $\left.\operatorname{nTA}(\mu \mathrm{mol} \mathrm{kg})^{-1}\right)$

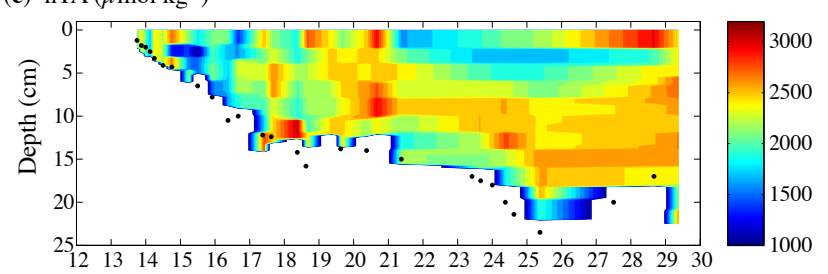

(d) $\mathrm{nTCO}_{2}(\mu \mathrm{mol} \mathrm{kg}-1)$

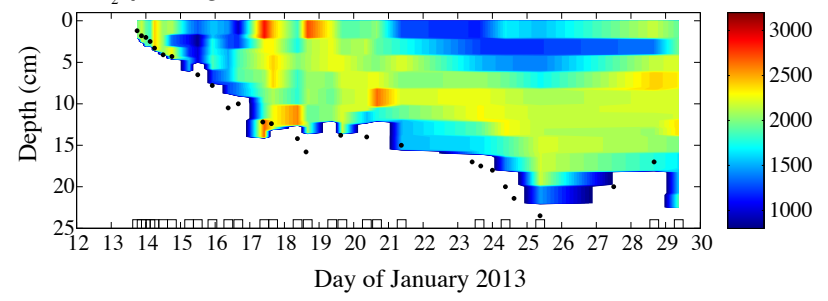

Figure 4. Evolution of (a) $\mathrm{TA}_{\text {(ice) }}\left(\mu \mathrm{molkg}{ }^{-1}\right)$, (b) $\mathrm{TCO}_{2 \text { (ice) }}$ $\left(\mu \mathrm{molkg} \mathrm{kg}^{-1}\right)$, (c) $\mathrm{nTA}_{\text {(ice) }}\left(\mu \mathrm{molkg} \mathrm{kg}^{-1}\right)$ and (d) $\mathrm{nTCO}_{2 \text { (ice) }}$ $\left(\mu \mathrm{mol} \mathrm{kg}{ }^{-1}\right)$. Sea ice thickness is illustrated by black dots. Open squares in the lower part of (d) mark the sampling times.

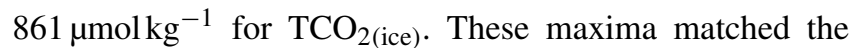
high bulk ice salinity (Fig. 2), so we also normalized $\mathrm{TA}_{\text {(ice) }}$ and $\mathrm{TCO}_{2 \text { (ice) }}$ (noted as $\mathrm{nTA}_{\text {(ice) }}$ and $\mathrm{nTCO}_{2 \text { (ice) }}, \mathrm{Fig}$. 4) to a salinity of 33 (according to the Reactions R4 and R5) to discard the effect of salinity changes and facilitate comparison with the underlying seawater. During initial sea ice formation (up to 17 January), the concentration of both $\mathrm{nTA}_{\text {(ice) }}$ (from 1083 to 2741 , average $1939 \mu \mathrm{mol} \mathrm{kg}^{-1}$ ) and $\mathrm{nTCO}_{2 \text { (ice) }}$ (from 853 to 2440 , average $1596 \mu \mathrm{mol} \mathrm{kg}^{-1}$ ) were at their minima in the experimental time series. From 17 to 21 January, both $\mathrm{nTA}_{\text {(ice) }}$ and $\mathrm{nTCO}_{2 \text { (ice) }}$ increased throughout the ice column (average $\mathrm{nTA}_{\text {(ice) }} 2375 \mu \mathrm{mol} \mathrm{kg}^{-1}$ and $\mathrm{nTCO}_{2 \text { (ice) }}$ $2117 \mu \mathrm{mol} \mathrm{kg}^{-1}$ ). However, from 21 January until the initial sea ice melt, $\mathrm{nTA}_{\text {(ice) }}$ and $\mathrm{nTCO}_{2 \text { (ice) }}$ decreased in the top $5 \mathrm{~cm}$ of the ice cover (average $\mathrm{nTA}_{\text {(ice) }} 2125 \mu \mathrm{mol} \mathrm{kg}^{-1}$ and $\mathrm{nTCO}_{2 \text { (ice) }} 1635 \mu \mathrm{mol} \mathrm{kg}^{-1}$ ).

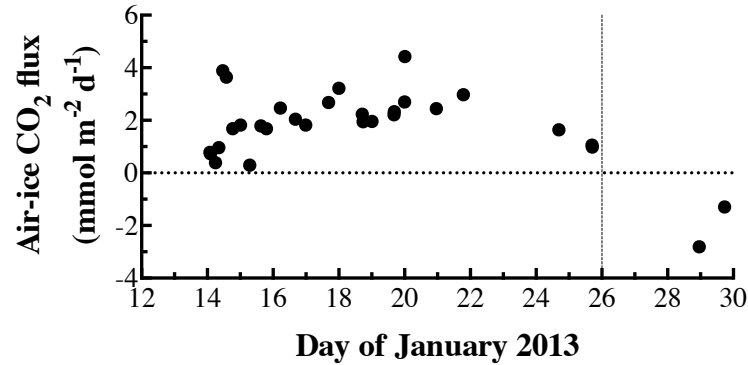

Figure 5. Air-ice $\mathrm{CO}_{2}$ fluxes $\left(\mathrm{mmolm}^{-2} \mathrm{~d}^{-1}\right)$. Positive air-ice $\mathrm{CO}_{2}$ flux means outgassing from the ice, and negative $\mathrm{CO}_{2}$ flux means uptake of atmospheric $\mathrm{CO}_{2}$. The vertical black dotted line on 26 January marks when the heat was turned back on.

\subsection{Air-ice $\mathrm{CO}_{2}$ fluxes}

The $\mathrm{CO}_{2}$ fluxes measured at the variably snow-covered sea ice surface (Fig. 2b), which ranged from 0.29 to $4.43 \mathrm{mmol} \mathrm{m}^{-2} \mathrm{~d}^{-1}$, show that growing sea ice released $\mathrm{CO}_{2}$ to the atmosphere (Fig. 5). However, as soon as the ice started to warm up and then melt, the sea ice switched from source to sink for atmospheric $\mathrm{CO}_{2}$, with downward fluxes from -1.3 to $-2.8 \mathrm{mmol} \mathrm{m}^{-2} \mathrm{~d}^{-1}$. These ranges of air-ice $\mathrm{CO}_{2}$ exchanges are of the same order of magnitude as fluxes reported on natural sea ice using the same chamber technique in the Arctic during the initial sea ice growth (from 4.2 to $9.9 \mathrm{mmol} \mathrm{m}^{-2} \mathrm{~d}^{-1}$ in Geilfus et al., 2013a) and during the spring-summer transition (from -1.4 to $-5.4 \mathrm{mmol} \mathrm{m}^{-2} \mathrm{~d}^{-1}$ in Geilfus et al., 2015). In Antarctica, air-ice $\mathrm{CO}_{2}$ fluxes were reported during the spring-summer transition from 1.9 to $-5.2 \mathrm{mmol} \mathrm{m}^{-2} \mathrm{~d}^{-1}$ by Delille et al. (2014), from 0.3 to $-2.9 \mathrm{mmol} \mathrm{m}^{-2} \mathrm{~d}^{-1}$ (Geilfus et al., 2014) and from 0.5 to $-4 \mathrm{mmol} \mathrm{m}^{-2} \mathrm{~d}^{-1}$ (Nomura et al., 2013).

\section{Discussion}

\subsection{Key processes affecting the carbonate system}

The dynamics of inorganic carbon in the ocean and sea ice are mainly affected by temperature and salinity changes, precipitation and dissolution of calcium carbonate and biological activities (Zeebe and Wolf-Gladrow, 2001). During this experiment, neither organic matter nor biota were purposely introduced into the pool; the observed range of bulk ice microbial activity $\left(5.7 \times 10^{-9}\right.$ on 14 January to $7.5 \times 10^{-7} \mathrm{~g} \mathrm{CL}^{-1} \mathrm{~h}^{-1}$ on 21 January) and algal chl $a(0.008$ on 14 January to $0.002 \mu \mathrm{g} \mathrm{L}^{-1}$ on 21 January) were too low to support any biological activity (Rysgaard et al., 2014). Therefore biological activity is unlikely to have played a role. During the same 2013 time series at SERF, Rysgaard et al. (2014) discussed the precipitation of ikaite within the ice cover in detail, reporting high concentrations of ikaite $\left.(>2000 \mu \mathrm{mol} \mathrm{kg})^{-1}\right)$ at the surface of the ice in brine skim and 
(a)

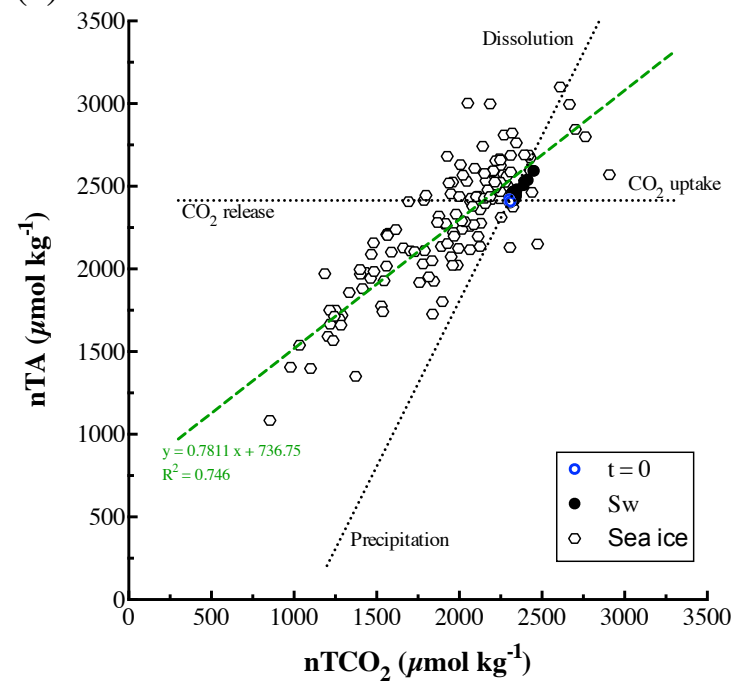

(b)

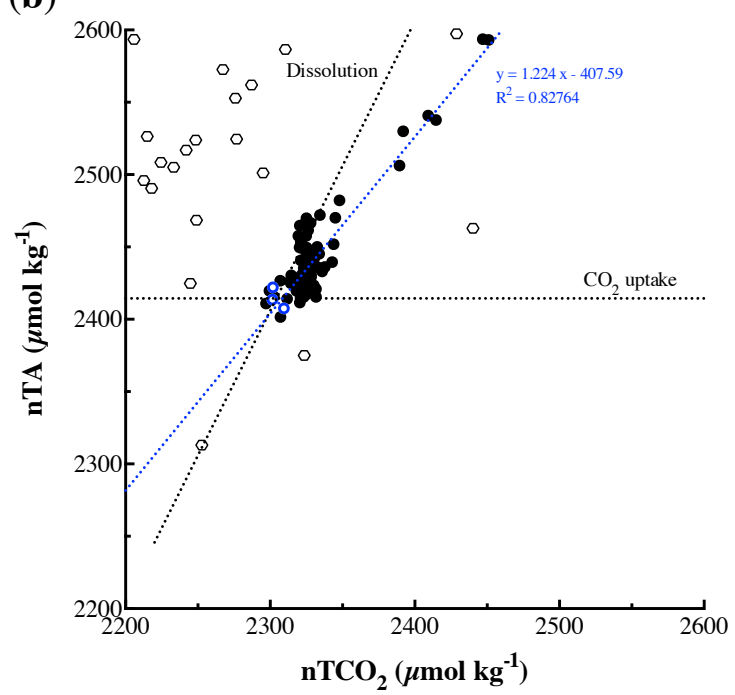

Figure 6. (a) Relationship between $\mathrm{nTCO}_{2}$ and nTA $\left(\mu \mathrm{mol} \mathrm{kg}{ }^{-1}\right.$ ) in bulk sea ice (white hexagons) and seawater (black dots). (b) Zoomed-in image of seawater data. The different dotted lines represent the theoretical evolution of nTA and nTCO $\mathrm{n}_{2}$ ratio following the precipitation/dissolution of calcium carbonate and release/uptake of $\mathrm{CO}_{2(\mathrm{~g})}$. A linear regression is shown in green for the ice samples (a) and blue for the seawater samples (b).

frost flowers, and ikaite precipitation up to $350 \mu \mathrm{mol} \mathrm{kg}-1$ within bulk sea ice. Within sea ice, ikaite precipitation is associated with low ice temperatures, high bulk salinity and high $\mathrm{TA}_{\text {(ice) }}$ and $\mathrm{TCO}_{2 \text { (ice) }}$ concentrations (Figs. 2, 3).

The main processes affecting the carbonate system can be described by changes in TA and $\mathrm{TCO}_{2}$ (Zeebe and WolfGladrow, 2001). An exchange of $\mathrm{CO}_{2 \text { (gas) }}$ affects $\mathrm{TCO}_{2}$, while TA remains constant and the precipitation-dissolution of calcium carbonate affects both $\mathrm{TA}$ and $\mathrm{TCO}_{2}$ in a ratio of $2: 1$ (see Reactions R1-R3, Fig. 6). To calculate the theoretical changes in TA and $\mathrm{TCO}_{2}$ during the course of the experiment, we used seawater samples from 11 January prior to sea ice formation ( $t=0$, Table 1$)$ as the origin point (blue circle on Fig. 6). Sea ice data are located between the theoretical calcium carbonate precipitation line and the $\mathrm{CO}_{2}$ release line (Fig. 6a), while seawater data mainly fall on the calcium carbonate dissolution line (Fig. 6b), suggesting that the carbonate system within sea ice is affected by both the precipitation of ikaite and a release of $\mathrm{CO}_{2 \text { (gas) }}$, while the underlying seawater is mainly affected by the dissolution of calcium carbonate.

\subsection{Estimation of the precipitation-dissolution of ikaite}

During the experiment, Rysgaard et al. (2014) observed ikaite within sea ice using direct microscopic observations. The precipitation-dissolution of ikaite and gas exchange are the only two processes taking place during the experiment. As illustrated in Fig. 6, an exchange of $\mathrm{CO}_{2}$ does not affect TA, while the precipitation-dissolution of ikaite affects TA and $\mathrm{TCO}_{2}$ in a ratio $2: 1$. Therefore, we use TA to estimate how much ikaite is precipitated or dissolved within the ice cover and the underlying seawater.

Assuming no biological effect, ikaite precipitation/dissolution and gas exchange, TA and $\mathrm{TCO}_{2}$ are considered conservative with salinity. Therefore, we can calculate the expected TA and $\mathrm{TCO}_{2}$ (noted as $\mathrm{TA}_{\text {(ice) }}^{*}$ and $\mathrm{TCO}_{2 \text { (ice) }}^{*}$ in the ice cover and $\mathrm{TA}_{(\mathrm{sw})}^{*}$ and $\mathrm{TCO}_{2(\mathrm{sw})}^{*}$ for the water column) based on the initial seawater conditions $\left(\mathrm{TA}_{(\mathrm{sw})}, \mathrm{TCO}_{2(\mathrm{sw})}\right.$ and $S_{(\mathrm{sw})}$ at $t=0$, Table 1$)$ and the sample salinity (bulk sea ice or seawater) measured during the experiment:

$\mathrm{TA}_{(\text {sample })}^{*}=\frac{\mathrm{TA}_{(\mathrm{sw}) t=0}}{S_{(\mathrm{sw}) t=0}} \times S_{(\text {sample })}$,
$\mathrm{TCO}_{2(\text { sample) } t}^{*}=\frac{\mathrm{TCO}_{2(\mathrm{sw}) t=0}}{S_{(\mathrm{sw}) t=0}} \times S_{(\text {sample })}$,

where $t$ is the time of the sampling. Within the ice cover, $\mathrm{TA}_{\text {(ice) }}$, $\mathrm{TCO}_{2 \text { (ice) }}$ and the bulk ice salinity are averaged throughout the ice column on each sampling day (Fig. 7a, b, black line), while for the underlying seawater, we used the averaged $\mathrm{TA}_{(\mathrm{sw})}, \mathrm{TCO}_{2(\mathrm{sw})}$ and salinity for all the measured depths (Fig. 2a, b, black line). The difference between $\mathrm{TA}_{\text {(sample) }}^{*}$ and the observed TA is only due to the precipitation or dissolution of ikaite crystals. In case of ikaite precipitation (i.e., $\mathrm{TA}_{(\text {sample) }}^{*}>\mathrm{TA}_{(\text {sample })}$ ), half of this positive difference corresponds to the amount of ikaite precipitated within the ice. This ikaite may either remain or may be exported out of the ice. A negative difference (i.e., $\mathrm{TA}_{(\text {sample })}^{*}<\mathrm{TA}_{(\text {sample) })}$ indicates ikaite dissolution. 
(a)

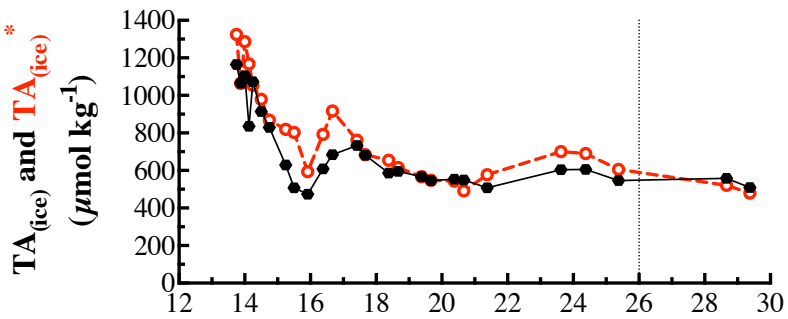

(b)

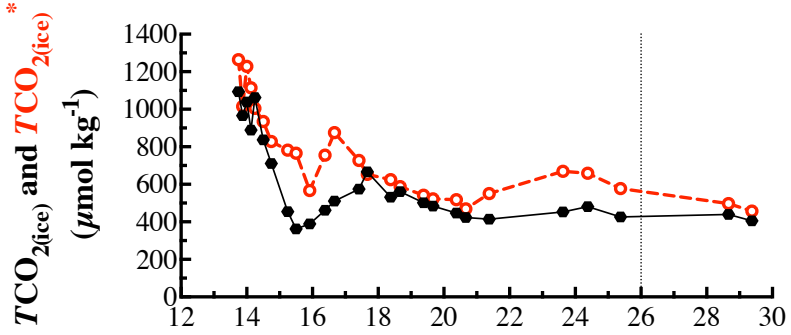

(c)

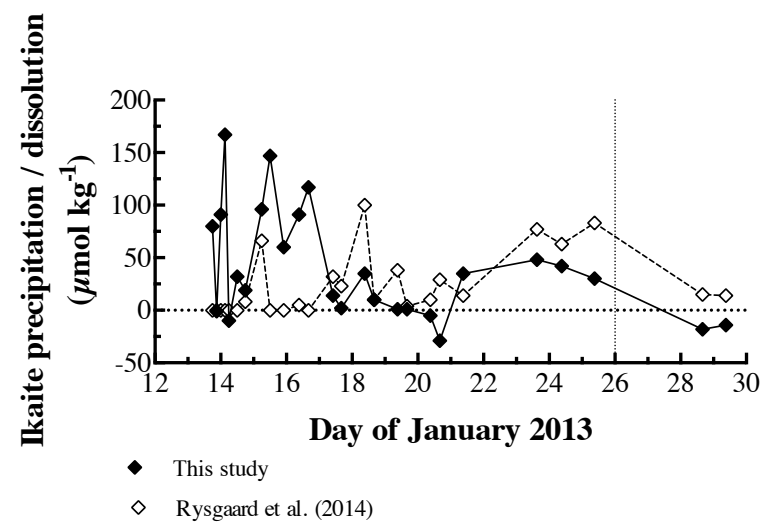

Figure 7. Evolution of (a) $\mathrm{TA}_{(\text {(ice) }}$ averaged throughout the ice thickness on each sampling day (black dots) and $\mathrm{TA}_{\text {(ice) }}^{*}$ (dashed red line) $\left(\mu \mathrm{mol} \mathrm{kg}^{-1}\right)$ and (b) $\mathrm{TCO}_{2 \text { (ice) }}$ averaged throughout the ice thickness on each sampling day (black diamonds) and $\mathrm{TCO}_{2 \text { (ice) }}^{*}$ (dashed red line) $\left(\mu \mathrm{mol} \mathrm{kg}{ }^{-1}\right)$. (c) Estimation of the ikaite precipitation/dissolution from half of the difference between $\mathrm{TA}_{\text {(ice) }}^{*}$ and $\mathrm{TA}_{\text {(ice) }}\left(\mu \mathrm{mol} \mathrm{kg}{ }^{-1}\right)$ (black diamonds) compared to the average amount of ikaite precipitated throughout the ice thickness for each sampling day from Rysgaard et al. (2014) (white dots). The vertical black dotted line on 26 January marks when the heat was turned back on.

\subsubsection{Sea ice}

Greater $\mathrm{TA}_{\text {(ice) }}^{*}$ and $\mathrm{TCO}_{2 \text { (ice) }}^{*}$ compared to the averaged observed $\mathrm{TA}_{\text {(ice) }}$ and $\mathrm{TCO}_{2 \text { (ice) }}$ (Fig. $7 \mathrm{a}$, b) are expected as ikaite is precipitated and $\mathrm{CO}_{2}$ is released from the ice to the atmosphere (Figs. 5, 6). Half the difference between $\mathrm{TA}_{\text {(ice) }}^{*}$ and $\mathrm{TA}_{(\text {ice) }}$ is a result of ikaite precipitation (Fig. 7c, black diamonds). Highly variable ikaite precipitation was observed (Fig. 7c). Ikaite precipitation was up to $167 \mu \mathrm{mol} \mathrm{kg}^{-1}$ (e.g., first days of the experiment) and as low as $1 \mu \mathrm{mol} \mathrm{kg}^{-1}$

(e.g., 19 January). A negative difference between $\mathrm{TA}_{\text {(ice) }}^{*}$ and
$\mathrm{TA}_{\text {(ice) }}$ (i.e., ikaite dissolution) occurred on three occasions: 14, 20 and after 26 January (beginning of the sea ice melt). On these occasions, the ice cover was relatively warm due to warmer atmospheric temperatures (14 January), thicker snow cover insulating the ice cover from the cold atmosphere (20 January) or when heat was turned back on (after 26 January, Fig. 2). Relatively high sea ice temperatures likely promote ikaite dissolution in agreement with Rysgaard et al. (2014), who linked ikaite precipitation/dissolution to ice temperature. The upward percolation of seawater observed from 15 to 18 January might complicate the effect of sea ice temperature on ikaite formation because it was in part responsible for increased ice temperatures (Fig. 2b) and therefore increased the sea ice brine volumes (Fig. 2c). Increased vertical connectivity (permeability) of the network of liquid inclusions throughout the sea ice (Golden et al., 2007; Galley et al., 2015) would have allowed the export of ikaite crystals from the ice cover to the underlying seawater. However, while we calculated a negative difference between $\mathrm{TA}_{\text {(ice) }}^{*}$ and $\mathrm{TA}_{(\mathrm{ice})}$, ikaite crystals were observed by Rysgaard et al. (2014). We compared the direct microscopy observations by averaging the amount of ikaite precipitated throughout the ice thickness for each sampling day from Rysgaard et al. (2014) (Fig. 7c, white dots) with our estimation of the amount of ikaite based on the difference between $\mathrm{TA}_{\text {(ice) }}^{*}$ and $\mathrm{TA}_{\text {(ice) }}$ (Fig. 7c, black diamonds). Both ikaite measurements are of the same order of magnitude; however, the average $\left(22 \mu \mathrm{mol} \mathrm{kg}^{-1}\right)$ and maximum $\left(100 \mu \mathrm{mol} \mathrm{kg}{ }^{-1}\right)$ of direct observations presented by Rysgaard et al. (2014) were lower than our estimated average $\left(40 \mu \mathrm{mol} \mathrm{kg}^{-1}\right)$ and maximum of up to $167 \mu \mathrm{mol} \mathrm{kg}^{-1}$ over this whole experiment. Deviations are likely due to methodological differences. Here, sea ice samples were melted to subsample for TA and $\mathrm{TCO}_{2}$. Ikaite crystals may have dissolved during melting, leading to an underestimation of the total amount of ikaite precipitated in the ice. However, the difference between $\mathrm{TA}_{\text {(ice) }}^{*}$ and $\mathrm{TA}_{(\mathrm{ice})}$ provides an estimation of how much ikaite is precipitated in the ice cover, including those crystals potentially already exported to the underlying seawater. The method used by Rysgaard et al. (2014) avoids the bias of ikaite dissolution during sea ice melt with the caveat that crystals need to be large enough to be optically detected. If no crystals were observed, Rysgaard et al. (2014) assumed that no crystals were precipitated in the ice, though ikaite crystals could have been formed and then exported into the underlying seawater prior to microscopic observation of the sample, which may explain the difference observed between both methods during initial sea ice formation (15-18 January) when the ice was still very thin. In addition, the succession of upward percolation events could have facilitated the ikaite export from the ice cover to the underlying seawater. Estimations from both methods show similar concentrations when the ice (i) warmed due to snowfall (18-23 January) and (ii) cooled once the snow was removed (on 23 January). Once the ice started to melt (26 January), Rysgaard et al. (2014) reported a decrease in 
the ikaite precipitation, while in this study we reported a negative difference between $\mathrm{TA}_{(\text {ice) }}^{*}$ and $\mathrm{TA}_{(\text {ice) }}$, possibly indicating that ikaite dissolved in the ice.

\subsubsection{Water column}

The main process affecting the carbonate system in the underlying seawater in this study is the export of ikaite from the ice and its dissolution in the water column (Fig. 6). While a few studies of ikaite precipitation within sea ice carried out over open ocean hypothesized that ikaite remained trapped within the sea ice matrix (Rysgaard et al., 2007, 2013; Delille et al., 2014), the observed increase of $\operatorname{nTA}_{(\mathrm{sw})}$ (Fig. 3) suggests that ikaite precipitated within the ice cover was exported to the underlying seawater where the crystals were dissolved, as suggested by Fransson et al. (2013). Lower $\mathrm{TA}_{(\mathrm{sw})}^{*}$ and $\mathrm{TCO}_{2(\mathrm{sw})}^{*}$ compared to $\mathrm{TA}_{(\mathrm{sw})}$ and $\mathrm{TCO}_{2(\mathrm{sw})}$ (Fig. 3) confirm the dissolution of ikaite in the underlying seawater, as the dissolution of ikaite crystals will decrease both TA and $\mathrm{TCO}_{2}$ (Reactions R1-R3). Therefore, half the difference between $\mathrm{TA}_{(\mathrm{sw})}^{*}$ and $\mathrm{TA}_{(\mathrm{sw})}$ corresponds to the concentration of ikaite exported from the ice and dissolved in the underlying seawater (Fig. 8a). This concentration increased over time to a maximum of $66 \mu \mathrm{mol} \mathrm{kg} \mathrm{kg}^{-1}$.

During this experiment, $\operatorname{nTA}_{(\mathrm{sw})}$ increased by $128 \mu \mathrm{mol} \mathrm{kg}{ }^{-1}$, while nTCO $_{2(\mathrm{sw})}$ increased by $82 \mu \mathrm{mol} \mathrm{kg}{ }^{-1}$ (Fig. 3c). This suggests that $64 \mu \mathrm{molkg} \mathrm{kg}^{-1}$ of ikaite is dissolved compared to the $66 \mu \mathrm{mol} \mathrm{kg}-1$ estimated from the difference between $\mathrm{TA}_{(\mathrm{sw})}^{*}$ and $\mathrm{TA}_{(\mathrm{sw})}$. As a result of the effect of ikaite dissolution on the $2: 1$ ratio of $\mathrm{TA}: \mathrm{TCO}_{2}$, the dissolution of ikaite accounts for the entire increase of $\mathrm{nTA}_{(\mathrm{sw})}$ but only accounts for $64-66 \mu \mathrm{mol} \mathrm{kg}^{-1}$ of the $82 \mu \mathrm{molkg}^{-1}$ increase in $\mathrm{nTCO}_{2(\mathrm{sw})}$. Therefore, $16-18 \mu \mathrm{mol} \mathrm{kg}^{-1}$ (about $25 \%$ ) of the increase of $\mathrm{nTCO}_{2(\mathrm{sw})}$ cannot be explained by the dissolution of ikaite. The increase of both $\mathrm{nTA}_{(\mathrm{sw})}$ and $\mathrm{nTCO}_{2(\mathrm{sw})}$ is more significant once the ice starts to melt (26 January). During sea ice melt, increased vertical permeability resulting in increased liquid communication through the sea ice volume from below likely, in part, dissolved ikaite crystals still residing in the ice at that time, and also will have created a downward crystal export mechanism. As the ice melt advanced, patches of open water occurred at the surface of the pool. Therefore, uptake of atmospheric $\mathrm{CO}_{2}$ by the undersaturated seawater likely occurred, increasing the $\mathrm{TCO}_{2(\mathrm{sw})}$.

The dissolution of ikaite crystals could also have a strong impact on the $p \mathrm{CO}_{2(\mathrm{sw})}$. The water column was undersaturated compared to the atmosphere during the whole experiment (Fig. 3d). A release of $\mathrm{CO}_{2}$, from the ice to the atmosphere, was measured during sea ice growth (Fig. 5) in spite of the undersaturated $p \mathrm{CO}_{2(\mathrm{sw})}$. This suggests that airice $\mathrm{CO}_{2}$ fluxes are only due to the concentration gradient between the ice and the atmosphere (Geilfus et al., 2012; Nomura et al., 2013) but that sea ice exchanges $\mathrm{CO}_{2}$ with the atmosphere independently of the seawater concentration (a)
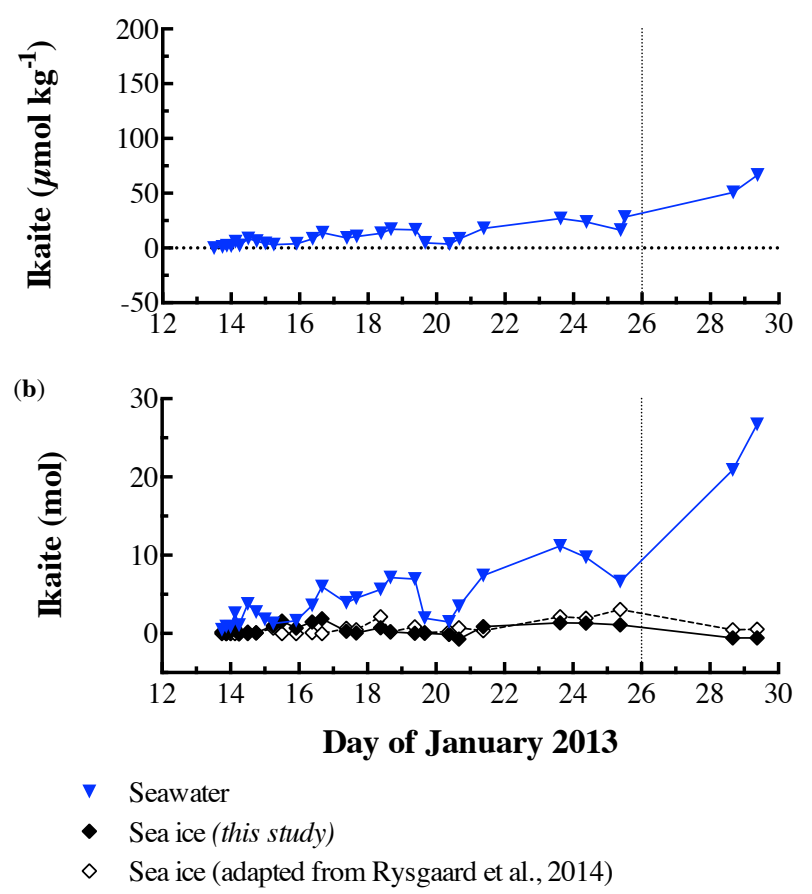

Figure 8. Evolution of (a) ikaite dissolution within the water column (in $\mu \mathrm{mol} \mathrm{kg}^{-1}$ ), (b) mass of ikaite dissolved in the underlying seawater (blue) and mass of ikaite precipitated in sea ice (black) estimated from this study and estimated from Rysgaard et al. (2014) (white). The vertical black dotted line on 26 January marks when the heat was turned back on.

(Geilfus et al., 2014). The $p \mathrm{CO}_{2 \text { (sw) }}$ is highly correlated with the seawater temperature (Fig. 2), with a rapid decrease of $p \mathrm{CO}_{2 \text { (sw) }}$ during the first days of the experiment (13-15 January) and a relative constant $p \mathrm{CO}_{2 \text { (sw) }}$ until 27 January. However, on 26 January, the heat was turned back on, affecting the seawater temperature on the same day (Fig. 2), while the impact of increasing temperature on the $p \mathrm{CO}_{2 \text { (sw) }}$ appeared 1 day later (Fig. 3d). We normalized the $p \mathrm{CO}_{2 \text { (sw) }}$ to a temperature of $-1{ }^{\circ} \mathrm{C}$ (after Copin-Montegut, 1988, noted as $\mathrm{n} p \mathrm{CO}_{2(\mathrm{sw})}$, blue line on Fig. $3 \mathrm{~d}$ ). The $\mathrm{n} p \mathrm{CO}_{2(\mathrm{sw})}$ does not show major variations during sea ice growth, with values around $380 \mu \mathrm{atm}$. However, once the heat is turned on and the seawater temperature increased (on 26 January), $\mathrm{n} p \mathrm{CO}_{2 \text { (sw) }}$ decreased from 383 to $365 \mu$ atm, while $p \mathrm{CO}_{2 \text { (sw) }}$ did not change in response to increased seawater temperatures until 27 January, suggesting that a process other than temperature change affected the $p \mathrm{CO}_{2(\mathrm{sw})}$. According to Reaction (R1), the dissolution of calcium carbonate has the potential to reduce $p \mathrm{CO}_{2 \text { (sw) }}$. Therefore, during sea ice growth and the associated release of salt, TA, $\mathrm{TCO}_{2}$ and ikaite crystals to the underlying seawater, ikaite dissolution within the seawater could be responsible for maintaining stable $p \mathrm{CO}_{2(\mathrm{sw})}$ values while seawater salinity, $\mathrm{TA}_{(\mathrm{sw})}$ and $\mathrm{TCO}_{2(\mathrm{sw})}$ are increasing. Once the seawater temperature increased (26 January), sea 
Table 2. Masses of $\mathrm{TCO}_{2}$ in the water column $\left(\mathrm{TCO}_{2(\mathrm{sw})}\right)$ and in the ice cover $\left(\mathrm{TCO}_{2(\mathrm{ice})}\right)$, masses of ikaite within the ice cover estimated from this study and from Rysgaard et al. (2014), masses of ikaite dissolved in the water column (Ikaite $\left(\mathrm{sw}_{)}\right)$and masses of $\mathrm{CO}_{2}$ exchanged between the ice and the atmosphere over the whole pool (estimation based on the air-ice $\mathrm{CO}_{2}$ fluxes). All units are in mol.

\begin{tabular}{|c|c|c|c|c|c|c|}
\hline $\begin{array}{l}\text { January } \\
\text { (DOY) }\end{array}$ & $\mathrm{TCO}_{2(\mathrm{sw})}$ & $\mathrm{TCO}_{2 \text { (ice) }}$ & $\begin{array}{l}\text { Ikaite }_{(\text {ice })} \\
\text { from this study }\end{array}$ & $\begin{array}{c}\text { Ikaite }_{(\text {ice })} \\
\text { from Rysgaard et al. (2014) }\end{array}$ & Ikaite $_{(\mathrm{sw})}$ & $\mathrm{CO}_{2 \text { (air-ice) }}$ \\
\hline$t=0$ & 1041 & - & - & - & - & - \\
\hline 13.75 & 1040 & 2.38 & 0.17 & 0.00 & 0.47 & - \\
\hline 13.88 & 1044 & 2.09 & 0.00 & 0.00 & 0.87 & - \\
\hline 14 & 1043 & 2.90 & 0.25 & 0.00 & 0.83 & 0.03 \\
\hline 14.13 & 1043 & 3.29 & 0.62 & 0.00 & 2.57 & 0.02 \\
\hline 14.25 & 1038 & 4.91 & -0.05 & 0.00 & 1.06 & 0.01 \\
\hline 14.5 & 1037 & 4.77 & 0.18 & 0.00 & 3.75 & 0.12 \\
\hline 14.75 & 1039 & 4.36 & 0.12 & 0.05 & 2.73 & 0.07 \\
\hline 15 & 1037 & - & - & - & 1.80 & 0.08 \\
\hline 15.25 & 1032 & 4.67 & 0.98 & 0.68 & 1.28 & 0.01 \\
\hline 15.5 & 1034 & 3.89 & 1.58 & 0.00 & -1.57 & 0.07 \\
\hline 15.92 & 1034 & 4.47 & 0.69 & 0.00 & 1.63 & 0.12 \\
\hline 16.38 & 1024 & 7.36 & 1.45 & 0.08 & 3.60 & 0.19 \\
\hline 16.67 & 1028 & 8.17 & 1.87 & 0.00 & 6.00 & 0.10 \\
\hline 17.38 & 1023 & 15.48 & 0.29 & 0.65 & 3.90 & 0.22 \\
\hline 17.67 & 1026 & 13.26 & 0.04 & 0.46 & 4.50 & 0.13 \\
\hline 18.38 & 1030 & 11.39 & 0.74 & 2.14 & 5.61 & 0.38 \\
\hline 18.67 & 1027 & 12.06 & 0.21 & 0.21 & 7.16 & 0.10 \\
\hline 19.38 & 1029 & 11.13 & 0.01 & 0.84 & 6.96 & 0.23 \\
\hline 19.67 & 1030 & 10.75 & 0.03 & 0.09 & 1.97 & 0.11 \\
\hline 20.38 & 1028 & 10.25 & -0.12 & 0.23 & 1.47 & 0.42 \\
\hline 20.67 & 1022 & 10.36 & -0.70 & 0.71 & 3.48 & 0.12 \\
\hline 21.38 & 1025 & 10.50 & 0.88 & 0.35 & 7.42 & 0.35 \\
\hline 23.63 & 1034 & 12.60 & 1.34 & 2.14 & 11.18 & - \\
\hline 24.38 & 1026 & 14.84 & 1.30 & 1.94 & 9.75 & 0.21 \\
\hline 25.38 & 1017 & 15.67 & 1.09 & 3.05 & 6.62 & - \\
\hline 25.5 & 1029 & - & & - & 11.51 & 0.02 \\
\hline 28.67 & 1022 & 13.46 & -0.57 & 0.46 & 20.91 & -0.93 \\
\hline 29.38 & 987.3 & 15.82 & -0.56 & 0.55 & 26.72 & -0.15 \\
\hline
\end{tabular}

ice melt likely released ikaite crystals to the underlying seawater (Figs. 2, 8a) along with brine and meltwater, a process that would continuously export ikaite from the sea ice as the volume interacting with the seawater via percolation or convection increased. The dissolution of these crystals likely contributed to keeping the $p \mathrm{CO}_{2(\mathrm{sw})}$ low and counterbalancing the effect of increased temperature. We argued that once all the ikaite crystals are dissolved, the increased seawater temperature increased the $p \mathrm{CO}_{2(\mathrm{sw})}$ simultaneously with the $\mathrm{n} p \mathrm{CO}_{2 \text { (sw) }}$ (27 January, Fig. 3).

\subsection{Ikaite export from the ice cover to the water column}

We estimated the amount of ikaite precipitated and dissolved within sea ice and seawater based on the sea ice (and seawater) volume (in $\mathrm{m}^{3}$ ), the sea ice and seawater density, the concentration of ikaite precipitated and dissolved within the ice cover (Fig. 7c) and the concentration of ikaite dissolved in the water column (Fig. 8a). Within the ice cover, the amount of ikaite precipitated/dissolved ranged from -0.7 to $1.97 \mathrm{~mol}$ (Fig. 8b, Table 2), with a maximum just after the snow was cleared on 23 January. In the underlying seawater, the amount of ikaite dissolved in the pool increased from $0.47 \mathrm{~mol}$ on the first day of the experiment to $11.5 \mathrm{~mol}$ on 25 January when sea ice growth ceased. Once the ice started to melt, the amount of dissolved ikaite increased up to 20.9 (28 January) and $26.7 \mathrm{~mol}$ (29 January, Table 2). The estimation of ikaite dissolution in the pool is significantly higher than the estimated amount of ikaite precipitated (and potentially exported) within the ice cover, especially during sea ice melt. Within the ice cover, the ikaite values presented here represent a snapshot of the ikaite content in the ice at the time of sampling. In the underlying seawater, ikaite dissolution increased $\mathrm{TA}_{(\mathrm{sw})}$ cumulatively over time.

The difference between $\mathrm{TA}_{\text {(ice) }}^{*}$ and $\mathrm{TA}_{\text {(ice) }}$ provides an estimation of ikaite precipitated within the ice, including potential ikaite export to the underlying seawater, so it cannot be used to determine how much ikaite remained in the ice 
vs. how much dissolved in the water column. However, Rysgaard et al. (2014) indicate that ikaite precipitated within the ice based on direct observations. Using the ikaite concentration reported in Rysgaard et al. (2014) (and shown in Fig. 7c), the sea ice volume $\left(\right.$ in $^{3}$ ) and density, we calculate that 0 $3.05 \mathrm{~mol}$ of ikaite precipitated within the ice cover during sea ice growth (Fig. 8b, Table 2). This amount decreased to 0.46 and 0.55 mol during the sea ice melt (28 and 29 January, respectively). Increased ikaite dissolution in the water column when the ice began to melt (from 11.5 to 20.9 mol) indicates that $9.4 \mathrm{~mol}$ of ikaite was stored in the ice and rejected upon the sea ice melt. This amount is about 3 times the amount of ikaite precipitated in the ice estimated by Rysgaard et al. (2014) at the end of the growth phase $(3.05 \mathrm{~mol}$, Table 2), suggesting more work is needed for the best estimate of ikaite precipitation within sea ice.

Once the ice started to melt, the increased ikaite dissolution from 11.5 to $20.9 \mathrm{~mol}$ (28 January) and to $26.7 \mathrm{~mol}$ (29 January) suggests that about the same amount of ikaite is dissolved during the sea ice growth as during the first 2 days of the sea ice melt. The amount of ikaite dissolved in the water column after melt commenced continued to increase cumulatively, suggesting that ikaite is continuously exported to the underlying seawater as increased sea ice temperatures permit more of the volume to communicate with the underlying seawater. Therefore, we can assume that more than half of the amount of ikaite precipitated within the ice remained in the ice cover before ice melt began.

\subsection{Air-ice-seawater exchange of inorganic carbon}

SERF is a semi-closed system where the only way for the surface (water or sea ice) to gain or lose $\mathrm{CO}_{2}$ is through exchange with the atmosphere, making it reasonable to track the exchange of $\mathrm{TCO}_{2}$ in the atmosphere-sea ice-seawater system. The ice cover always had lower $\mathrm{TCO}_{2 \text { (ice) }}$ during the experiment $\left(\mathrm{TCO}_{2 \text { (ice) }}^{*}>\mathrm{TCO}_{2 \text { (ice) })}\right.$ ) compared to what would be expected if the $\mathrm{CO}_{2}$ simply followed brine rejection in a conservative process (i.e., $\mathrm{TCO}_{2 \text { (ice) }}^{*}$ ) (Fig. 7b). This could be due to (i) $\mathrm{CO}_{2}$ released to the atmosphere from sea ice, (ii) decreased $\mathrm{TCO}_{2 \text { (ice) }}$ due to the precipitation of ikaite within sea ice and/or (iii) sea ice exchanging $\mathrm{TCO}_{2}$ with the underlying seawater.

The number of moles of $\mathrm{TCO}_{2}$ exchanged during this experiment was calculated using the sea ice (and seawater) volume (in $\mathrm{m}^{3}$ ) and density (in $\mathrm{kg} \mathrm{m}^{-3}$ ). The total amount of $\mathrm{TCO}_{2 \text { (ice) }}$ lost from the ice cover (the difference between

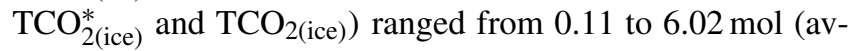
erage $2.38 \mathrm{~mol}$, Fig. 9, black dots). The greatest sea ice $\mathrm{TCO}_{2}$ losses occurred on 15-16 January, during initial sea ice growth, and from 23 to 25 January, during ice cooling due to snow removal. The exchange of $\mathrm{CO}_{2}$ between the ice and the atmosphere is known (Fig. 5). The number of moles of $\mathrm{CO}_{2}$ exchanges between the ice and the atmosphere was calculated (noted as $\mathrm{CO}_{2 \text { (air-ice) }}$ in Table 2) using the time

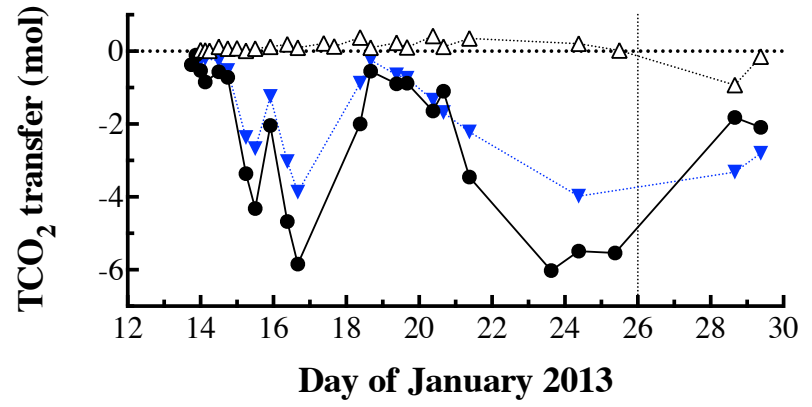

- Total amount of $\mathrm{TCO}_{2}$ lost from sea ice

$\triangle \mathrm{CO}_{2 \text { air-ice }}$ exchange

$\nabla$ Ice-seawater $\mathrm{TCO}_{2}$ exchange

Figure 9. Total amount of $\mathrm{TCO}_{2}$ lost from the ice cover (black dots), amount of $\mathrm{CO}_{2}$ exchange between the atmosphere and the ice cover $\left(\mathrm{CO}_{2}\right.$ air-ice, white triangle) and sea ice-seawater $\mathrm{TCO}_{2}$ exchanges (blue triangle) measured in moles for each day, integrated over the whole tank. The dotted line on 26 January marks when the heat was turned back on.

step between each flux measurement, the ice thickness and the density. During sea ice growth, $0.01-0.42 \mathrm{~mol}$ of $\mathrm{CO}_{2}$ was released from the ice-covered pool to the atmosphere. During sea ice melt, uptake of atmospheric $\mathrm{CO}_{2}$ by the icecovered pool ranged from -0.15 to -0.93 (Fig. 9, white triangles). On average, over the duration of the experiment, the ice cover released $0.08 \mathrm{~mol}$ of $\mathrm{CO}_{2}$ to the atmosphere. Assuming we know how much ikaite is contained within the ice cover (Fig. 8b), we can estimate how much $\mathrm{TCO}_{2}$ is exported from the ice to the underlying seawater (Fig. 9, blue triangles) by subtracting the air-ice $\mathrm{CO}_{2}$ exchange and the ikaite precipitation from the total reduction of $\mathrm{TCO}_{2 \text { (ice) }}$ observed within the ice cover (Fig. 9, black dots). The sea ice-seawater $\mathrm{TCO}_{2}$ export ranged from 0.2 to $3.98 \mathrm{~mol}$ (average $=1.7 \mathrm{~mol}$ ), confirming that sea ice primarily exports $\mathrm{TCO}_{2}$ to the underlying seawater. $\mathrm{TCO}_{2}$ export from the ice to the water column ranged from $23 \%$ of the total sea ice $\mathrm{TCO}_{2}$ early in the ice growth (14 January) to $100 \%$ after the onset of melt. These estimations are comparable to the study of Sejr et al. (2011), who suggested that sea ice exports $99 \%$ of its total $\mathrm{TCO}_{2}$ to the seawater below it. On average over the whole experiment, sea ice exported $1.7 \mathrm{~mol}$ of $\mathrm{TCO}_{2}$ to the underlying seawater (Fig. 9), which corresponds to a $\mathrm{TCO}_{2 \text { (sw) }}$ increase of $43.5 \mu \mathrm{mol} \mathrm{kg}{ }^{-1}$ considering the average sea ice thickness and density during the experiment and the volume of the pool. However, $\mathrm{TCO}_{2(\mathrm{sw})}$ increased by $115 \mu \mathrm{mol} \mathrm{kg}^{-1}$ over the whole experiment (Fig. 3b), leaving an increase of $71.5 \mu \mathrm{mol} \mathrm{kg}^{-1}$ in the $\mathrm{TCO}_{2(\mathrm{sw})}$ that cannot be explained by the sea ice-seawater exchange of $\mathrm{TCO}_{2}$. We postulate that as the ice melt advanced, patches of open water that opened at the surface of the pool which were undersaturated compared to the atmosphere (Fig. 3d) imported the additional $\mathrm{TCO}_{2}$ directly from the atmosphere in the form 
of $\mathrm{CO}_{2(\mathrm{~g})}$. Considering the pool volume, the $71.5 \mu \mathrm{mol} \mathrm{kg}-1$ increase of $\mathrm{TCO}_{2(\mathrm{sw})}$ could be explained by an air-sea water $\mathrm{CO}_{2}$ uptake of $8.5 \mathrm{mmol} \mathrm{m}^{-2} \mathrm{~d}^{-1}$ over 3 days of sea ice melt in a $20 \%$ ice-free pool. High air-sea gas exchange rates have been observed over partially ice-covered seas (Else et al., 2011, 2013). This mechanism is also corroborated by models that account for additional sources of turbulence generated by the presence of sea ice (Loose et al., 2014).

The design of the experiment allowed for constrained measurements of inorganic carbon fluxes between sea ice and the water column not possible in a natural environment where large-volume mixing processes alter the underlying seawater, making it more complicated to identify changes. We build a $\mathrm{CO}_{2}$ budget based only on the sea ice growth phase because only 2 days of data for the melt phase are available, and the experiment stopped while the pool was $20 \%$ ice-free (Rysgaard et al., 2014; Else et al., 2015). The initial seawater (origin point, $t=0$ ) contained $1041 \mathrm{~mol}$ of $\mathrm{TCO}_{2(\mathrm{sw})}$ on 11 January, while on the last day of sea ice growth (25 January) the seawater contained $1017 \mathrm{~mol}$ of $\mathrm{TCO}_{2(\mathrm{sw})}$ (Table 2), with the difference $\left(24 \mathrm{~mol}\right.$ of $\left.\mathrm{TCO}_{2}\right)$ in all likelihood transferred from the water column to the ice cover or the atmosphere. However, the $\mathrm{TCO}_{2}$ content within the ice cover at the end of the growing phase was $15.6 \mathrm{~mol}$ and the ice cover released $3.1 \mathrm{~mol}$ of $\mathrm{CO}_{2}$ to the atmosphere (Table 2). Therefore, 4.9 of the $24 \mathrm{~mol}$ of $\mathrm{TCO}_{2}$ exchanged from the water column is unaccounted for, but may be explained by air-ice $\mathrm{CO}_{2}$ fluxes. The chamber measurement technique for air-ice $\mathrm{CO}_{2}$ flux may underestimate the exchange of $\mathrm{CO}_{2}$, and the air-seawater $\mathrm{CO}_{2}$ fluxes are unknown until the ice started to grow (13 January). These missing moles of $\mathrm{TCO}_{2}$ may also be explained by our assumption of uniform sea ice thickness in the SERF. Using the seawater conditions at the end of the experiment, $1 \mathrm{~cm}$ of seawater in the pool contains $4.21 \mathrm{~mol}$ of $\mathrm{TCO}_{2}$, making it difficult to close our budget.

\subsection{Potential impact of sea ice growth and ikaite export on aragonite saturation state of the underlying seawater}

The Arctic Ocean is a region where calcifying organisms are particularly vulnerable to ocean acidification since low temperatures and low salinity lower the carbonate saturation state. As a result, several areas of the Arctic Ocean are already undersaturated with respect to aragonite (Chierici and Fransson, 2009; Yamamoto-Kawai et al., 2009; Bates et al., 2011). This undersaturation is enhanced in winter as the temperature decreases and $p \mathrm{CO}_{2}$ increases as a result of respiration. Calcifying organisms might therefore be most susceptible to the effects of acidification in the winter, corresponding to the annual minimum in aragonite saturation state ( $\left.\Omega_{\text {aragonite }}\right)$. Sea ice retreat is thought to enhance the impact of ocean acidification by freshening and ventilating the surface water (Yamamoto-Kawai et al., 2008; Yamamoto et al., 2012; Popova et al., 2014). However, any understanding (a)

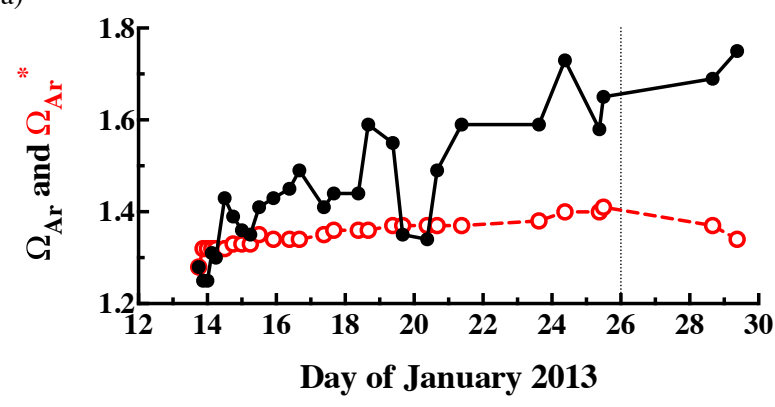

(b)

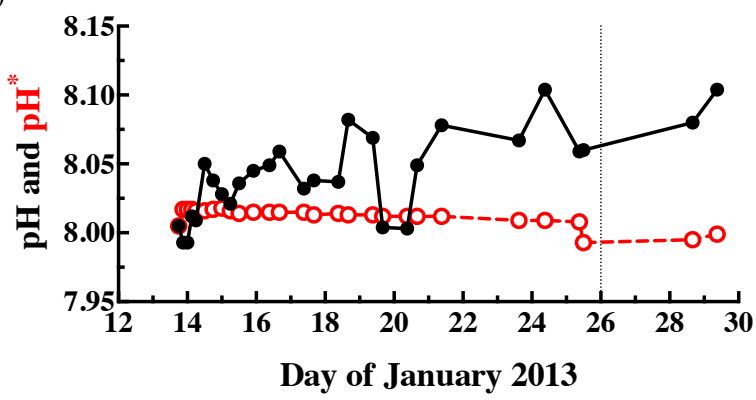

Figure 10. Evolution of (a) $\Omega_{\text {aragonite }}$ in the water column, calculated based on $\mathrm{TA}_{(\mathrm{sw})}$ and $\mathrm{TCO}_{2(\mathrm{sw})}$ (black dots) and calculated based on $\mathrm{TA}_{(\mathrm{sw})}^{*}$ and $\mathrm{TCO}_{2(\mathrm{sw})}^{*}$ (dashed red line), and (b) $\mathrm{pH}$ in the water column calculated based on $\mathrm{TA}_{(\mathrm{sw})}$ and $\mathrm{TCO}_{2(\mathrm{sw})}$ (black dots) and calculated based on $\mathrm{TA}_{(\mathrm{sw})}^{*}$ and $\mathrm{TCO}_{2(\mathrm{sw})}^{*}$ (dashed red line).

of the effect of ikaite precipitation in sea ice on ocean acidification is still in its infancy (e.g., Fransson et al., 2013).

Since the discovery of ikaite precipitation in sea ice (Dieckmann et al., 2008), research on its impact on the carbonate system of the underlying seawater has been ongoing. Depending on the timing and location of this precipitation within sea ice, the impact on the atmosphere and the water column in terms of $\mathrm{CO}_{2}$ transport can be significantly different (Delille et al., 2014). Dissolution of ikaite within melting sea ice in the spring and export of this related high $\mathrm{TA}: \mathrm{TCO}_{2}$ ratio meltwater from the ice to the water column will decrease the $p \mathrm{CO}_{2}$ and increase $\mathrm{pH}$ and $\Omega_{\text {aragonite }}$ of the surface layer seawater. Accordingly, during sea ice melt, an increase of $\Omega_{\text {aragonite }}$ in the surface water in the Arctic was observed (Chierici et al., 2011; Fransson et al., 2013; Bates et al., 2014). However, it was difficult to ascribe this increase to the legacy of excess TA in sea ice, ikaite dissolution or primary production.

The impact of ikaite precipitation on the surface seawater during sea ice growth is less clear. Fransson et al. (2013) suggested in winter in the Amundsen Gulf that the release of brine decreased $\Omega_{\text {aragonite }}$ by 0.8 at the sea ice-seawater interface as a result of ikaite precipitation within sea ice and the related $\mathrm{CO}_{2}$ enrichment of brine. Conversely, dur- 
ing ice melt, $\Omega_{\text {aragonite }}$ increased by 1.4 between March and May, likely due to both calcium carbonate dissolution and primary production. This contrasts with the present experiment. Figure 10 shows the evolution of $\Omega_{\text {aragonite }}$ and $\mathrm{pH}$ in the water column derived from $\mathrm{TA}_{(\mathrm{sw})}$ and $\mathrm{TCO}_{2(\mathrm{sw})}$ and the evolution of $\Omega_{\text {aragonite }}$ and $\mathrm{pH}$ predicted solely from salinity changes (i.e., using $\mathrm{TA}_{(\mathrm{sw})}^{*}$ and $\mathrm{TCO}_{2(\mathrm{sw})}^{*}$, noted as $\Omega_{\text {aragonite }}^{*}$ and $\mathrm{pH}^{*}$ ). We used the CO2sys_v2.1.xls spreadsheet (Pierrot et al., 2006) with the dissociation constants from Goyet and Dickson (1989) and all other constants from DOE (1994). This shows the complexity of ikaite and its impact on the carbonate system and $\Omega$ in the underlying water.

During ice growth, sea ice brine rejection appears to increase both pH (from 8.00 to 8.06) and $\Omega_{\text {aragonite (from } 1.28}$ to 1.65) of the underlying seawater, offsetting the effect of decreased temperature. A slight increase of $\Omega_{\text {aragonite }}$ was predicted due to increased salinity and a proportional increase of TA and $\mathrm{TCO}_{2}$ as depicted in $\Omega_{\text {aragonite }}^{*}$. However, the effect of ikaite rejection and subsequent changes in TA strongly enhance the increase of $\Omega_{\text {aragonite }}$. Therefore, ikaite rejection from sea ice has a much stronger potential to increase $\Omega_{\text {aragonite }}$ than brine rejection during fall and winter sea ice growth, suggesting ikaite exported to seawater from sea ice may hamper the effect of oceanic acidification on $\Omega_{\text {aragonite }}$ in fall and in winter at the time when $\Omega_{\text {aragonite }}$ is at its minimum (Chierici and Fransson, 2009; YamamotoKawai et al., 2009; Chierici et al., 2011). Ice formation may therefore delay harmful effects of ocean acidification on calcifying organisms by increasing $\Omega_{\text {aragonite }}$ in the critical winter period when $\Omega_{\text {aragonite }}$ reaches its minimal values. As a corollary, ice removal acts to alleviate the effect of ikaite rejection and may therefore lower $\Omega_{\text {aragonite }}$. This calls for an accounting of under-ice ikaite rejection in modeling predictions on the consequences of Arctic Ocean acidification in the context of northern hemispheric annual multiyear sea ice loss, as increased summer open water will lead to more firstyear sea ice formation in fall and winter in the future.

\section{Conclusion}

We quantified the evolution of inorganic carbon dynamics from initial sea ice formation to its melt in a sea ice-seawater mesocosm pool from 11 to 29 January 2013. Based on our analysis of TA and $\mathrm{TCO}_{2}$ in sea ice and seawater, the main processes affecting inorganic carbon within sea ice are ikaite precipitation and $\mathrm{CO}_{2}$ exchange with the atmosphere, while in the underlying seawater, dissolution of ikaite was the main process affecting the inorganic carbon system.

During this experiment, sea ice exchanged inorganic carbon components (e.g., $\mathrm{CO}_{2}$, ikaite, $\mathrm{TCO}_{2}$ ) with both the atmosphere and the underlying seawater. During sea ice growth, $\mathrm{CO}_{2}$ was released to the atmosphere, while during ice melt, an uptake of atmospheric $\mathrm{CO}_{2}$ was observed. We re- port ikaite precipitation of up to $167 \mu \mathrm{mol} \mathrm{kg}^{-1}$ sea ice, similar to previous estimates from Rysgaard et al. (2014) based on microscopically observed values. In the underlying seawater, a net increase of $\mathrm{nTA}_{(\mathrm{sw})}$ over the whole experiment was observed (up to $128 \mu \mathrm{mol} \mathrm{kg}^{-1}$ ), suggesting that a portion of the ikaite crystals precipitated within sea ice was exported to the underlying seawater and then dissolved as the ice cover evolved in time. Ikaite export from ice to the underlying seawater was associated with brine rejection during sea ice growth, increased sea ice vertical connectivity due to the upward percolation of seawater and meltwater flushing during sea ice melt. Rysgaard et al. (2007) suggested that ikaite precipitation within sea ice could act as a significant sink for atmospheric $\mathrm{CO}_{2}$; however to act as a sink for atmospheric $\mathrm{CO}_{2}$, ikaite crystals must remain in the ice structure while the $\mathrm{CO}_{2}$ produced by their precipitation is expelled with dense brine rejection and entrained in deep seawater (Delille et al., 2014). TA changes observed in the water column once the sea ice started to melt indicate that more than half of the total amount of ikaite precipitated in the ice during the sea ice growth remained in the ice until the sea ice began to melt. Derivation of air-sea $\mathrm{CO}_{2}$ fluxes related to the sea ice carbon pump should take into account ikaite export to the underlying ocean during sea ice growth, which might reduce the efficiency of oceanic $\mathrm{CO}_{2}$ uptake upon sea ice melt. As sea ice melts, ikaite is flushed downward out of the ice along with the meltwater.

Ikaite export from sea ice and its dissolution had a strong impact on the underlying seawater. In this semi-closed system, sea ice growth increased the seawater salinity, $\mathrm{TA}_{(\mathrm{sw})}$ and $\mathrm{TCO}_{2(\mathrm{sw})}$. In spite of these increases, the $p \mathrm{CO}_{2}$ of the underlying seawater remained undersaturated compared to the atmosphere. We conclude that ikaite dissolution within the water column is responsible for the seawater's continual $p \mathrm{CO}_{2}$ undersaturation. In addition, we discuss that dissolution of ikaite crystals exported from sea ice in the underlying seawater can potentially hamper the effect of oceanic acidification on $\Omega_{\text {aragonite }}$ in fall and in winter in ice-covered areas at the time when $\Omega_{\text {aragonite }}$ is smallest.

\section{Data availability}

Data are available upon request from the authors.

Acknowledgements. We gratefully acknowledge the contributions of the Canada Excellence Research Chair (CERC) and Canada Research Chair (CRC) programs. Support was also provided by the Natural Sciences and Engineering Research Council (NSERC), the Canada Foundation for Innovation and the University of Manitoba. Ryan J. Galley thanks the NSERC Discovery Grant program. Bruno Delille is a research associate of the F.R.S.-FNRS. This work is a contribution to the ArcticNet Networks of Centres of Excellence and the Arctic Science Partnership (ASP; asp-net.org) 
and the ARC cake club. The authors are grateful to the anonymous reviewers and to the editor whose comments greatly improved the quality of the manuscript.

Edited by: L. Kaleschke

Reviewed by: four anonymous referees

\section{References}

Bates, N. R. and Mathis, J. T.: The Arctic Ocean marine carbon cycle: evaluation of air-sea $\mathrm{CO}_{2}$ exchanges, ocean acidification impacts and potential feedbacks, Biogeosciences, 6, 2433-2459, doi:10.5194/bg-6-2433-2009, 2009.

Bates, N. R., Cai, W. J., and Mathis, J. T.: The ocean carbon cycle in the western Arctic Ocean: Distributions and air-sea fluxes of carbon dioxide, Oceanography, 24, 186-201, 2011.

Bates, N. R., Garley, R., Frey, K. E., Shake, K. L., and Mathis, J. T.: Sea-ice melt $\mathrm{CO}_{2}$-carbonate chemistry in the western Arctic Ocean: meltwater contributions to air-sea $\mathrm{CO}_{2}$ gas exchange, mixed-layer properties and rates of net community production under sea ice, Biogeosciences, 11, 6769-6789, doi:10.5194/bg11-6769-2014, 2014.

Chierici, M. and Fransson, A.: Calcium carbonate saturation in the surface water of the Arctic Ocean: undersaturation in freshwater influenced shelves, Biogeosciences, 6, 2421-2431, doi:10.5194/bg-6-2421-2009, 2009.

Chierici, M., Fransson, A., Lansard, B., Miller, L. A., Mucci, A., Shadwick, E., Thomas, E., Tremblay, J. E., and Papakyriakou, T.: The impact of biogeochemical processes and environmental factors on the calcium carbonate saturation state in the Circumpolar Flaw Lead in the Amundsen Gulf, Arctic Ocean, J. Geophys. Res., 116, C00G09, doi:10.1029/2011JC007184, 2011.

Copin-Montégut, C.: A new formula for the effect of temperature on the partial pressure of carbon dioxide in seawater, Mar. Chem., 25, 29-37, 1988.

Cox, G. F. N. and Weeks, W. F.: Equations for determining the gas and brine volumes in sea-ice samples, J. Glaciol., 29, 306-316, 1983.

Delille, B., Vancoppenolle, M., Geilfus, N.-X., Tilbrook, B., Lannuzel, D., Schoemann, V., Becquevort, S., Carnat, G., Delille, D., Lancelot, C., Chou, L., Dieckmann, G. S., and Tison, J.L.: Southern Ocean $\mathrm{CO}_{2}$ sink: The contribution of the sea ice, J. Geophys. Res.-Oceans, 119, 6340-6355, 2014.

Dieckmann, G. S., Nehrke, G., Papadimitriou, S., Gottlicher, J., Steininger, R., Kennedy, H., Wolf-Gladrow, D., and Thomas, D. N.: Calcium carbonate as ikaite crystals in Antarctic sea ice, Geophys. Res. Lett., 35, L08501, doi:10.1029/2008GL033540, 2008.

DOE: Handbook of methods for the analysis of the various parameters of the carbon dioxide system in sea water; version 2, edited by: Dickson, A. G. and Goyet, C., ORNL/CDIAC-74, 1994.

Ducklow, H. W.: Seasonal production and bacterial utilization of DOC in the Ross Sea, Antarctica, Biogeochemistry of the Ross Sea, 78, 143-158, 2003.

Else, B. G. T., Papakyriakou, T., Galley, R., Drennan, W. M., Miller, L. A., and Thomas, H.: Wintertime $\mathrm{CO}_{2}$ fluxes in an Arctic polynya using eddy covariance: Evidence for enhanced air-gas transfer during ice formation, J. Geophys. Res., 116, C00G03, doi:10.1029/2010JC006760, 2011.

Else, B. G. T., Galley, R. J., Lansard, B., Barber, D. G., Brown, K., Miller, L. A., Mucci, A., Papakyriakou, T. N., Tremblay, J. E., and Rysgaard, S.: Further observations of a decreasing atmospheric $\mathrm{CO}_{2}$ uptake capacity in the Canada Basin (Arctic Ocean) due to sea ice loss, Geophys. Res. Lett., 40, 1132-1137, 2013.

Else, B. G. T., Rysgaard, S., Attard, K., Campbell, K., Crabeck, O., Galley, R. J., Geilfus, N. X., Lemes, M., Lueck, R., Papakyriakou, T., and Wang, F.: Under-ice eddy covariance flux measurements of heat, salt, momentum, and dissolved oxygen in an artificial sea ice pool, Cold Reg. Sci. Technol., 119, 158-169, 2015.

Frankignoulle, M.: Field-Measurements of Air Sea $\mathrm{CO}_{2}$ Exchange, Limnol. Oceanogr., 33, 313-322, 1988.

Fransson, A., Chierici, M., Miller L. A., Carnat G., Shadwick, E., Thomas, H., Pineault, S., and Papakyriakou, T. N.: Impact of seaice processes on the carbonate system and ocean acidification at the ice-water interface of the Amundsen Gulf, Arctic Ocean, J. Geophys. Res.-Oceans, 118, 7001-7023, 2013.

Galley, R. J., Else, B. G. T., Geilfus, N. X., Hare, A. A., Isleifson, D., Barber, D. G., and Rysgaard, S.: Imaged brine inclusions in young sea ice-Shape, distribution and formation timing, Cold Reg. Sci. Technol., 111, 39-48, 2015.

Garneau, M. È., Vincent, W. F., Alonso-Sáez L., Gratton, Y., and Lovejoy, C.: Prokaryotic community structure and heterotrophic production in a river-influenced coastal arctic ecosystem, Aquat. Microb. Ecol., 32, 27-40, 2006.

Geilfus, N.-X., Carnat, G., Papakyriakou, T., Tison, J. L., Else, B., Thomas, H., Shadwick, E., and Delille, B.: Dynamics of $\mathrm{pCO}_{2}$ and related air-ice $\mathrm{CO}_{2}$ fluxes in the Arctic coastal zone (Amundsen Gulf, Beaufort Sea), J. Geophys. Res., 117, C00G10, doi:10.1029/2011JC007118, 2012.

Geilfus, N.-X., Carnat, G., Dieckmann, G. S., Halden, N., Nehrke, G., Papakyriakou, T., Tison, J. L., and Delille, B.: First estimates of the contribution of $\mathrm{CaCO}_{3}$ precipitation to the release of $\mathrm{CO}_{2}$ to the atmosphere during young sea ice growth, J. Geophys. Res.Oceans, 118, 244-255, doi:10.1029/2012JC007980, 2013a.

Geilfus, N.-X., Galley, R. J., Cooper, M., Halden, N., Hare, A., Wang, F., Søgaard, D. H., and Rysgaard, S.: Gypsum crystals observed in experimental and natural sea ice, Geophys. Res. Lett., 40, 6362-6367, doi:10.1002/2013GL058479, 2013b.

Geilfus, N.-X., Tison, J.-L., Ackley, S. F., Galley, R. J., Rysgaard, S., Miller, L. A., and Delille, B.: Sea ice $p \mathrm{CO}_{2}$ dynamics and air-ice $\mathrm{CO}_{2}$ fluxes during the Sea Ice Mass Balance in the Antarctic (SIMBA) experiment - Bellingshausen Sea, Antarctica, The Cryosphere, 8, 2395-2407, doi:10.5194/tc8-2395-2014, 2014.

Geilfus, N.-X., Galley, R. J., Crabeck, O., Papakyriakou, T., Landy, J., Tison, J.-L., and Rysgaard, S.: Inorganic carbon dynamics of melt-pond-covered first-year sea ice in the Canadian Arctic, Biogeosciences, 12, 2047-2061, doi:10.5194/bg-12-2047-2015, 2015.

Golden, K. M., Eicken, H., Heaton, A. L., Miner, J., Pringle, D. J., and Zhu, J.: Thermal evolution of permeability and microstructure in sea ice, Geophys. Res. Lett., 34, L16501, doi:10.1029/2007GL030447, 2007.

Goyet, C. and Poisson, A.: New determination of carbonic acid dissociation constants in seawater as a function of temperature and salinity, Deep-Sea Res., 36, 1635-1654, 1989. 
Grasshoff, K., Ehrhardt, M., and Kremling, K.: Methods of sea water analysis, Verlag Chemie, 1983.

Hansen, J. W., Thamdrup, B., and Jørgensen, B. B.: Anoxic incubation of sediment in gas-tight plastic bags: a method for biogeochemical processes studies, Mar. Ecol.-Prog. Ser., 208, 273-282, 2000.

Haraldsson, C., Anderson, L. G., Hassellov, M., Hulth, S., and Olsson, K.: Rapid, high-precision potentiometric titration of alkalinity in ocean and sediment pore waters, Deep-Sea Res. Pt. I, 44, 2031-2044, 1997.

Hare, A. A., Wang, F., Barber, D., Geilfus, N. X., Galley, R. J., and Rysgaard, S.: pH Evolution in sea ice grown at an outdoor experimental facility, Mar. Chem., 154, 46-54, 2013.

Johnson, K. M., Sieburth, J. M., Williams, P. J. L., and Brandstrom, L.: Coulometric total carbon-dioxide analysis for marine studies - automation and calibration, Mar. Chem., 21, 117-133, 1987.

Killawee, J. A., Fairchild, I. J., Tison, J. L., Janssens, L., and Lorrain, R.: Segregation of solutes and gases in experimental freezing of dilute solutions: Implications for natural glacial systems, Geochim. Cosmochim. Ac., 62, 3637-3655, 1998.

Kirchmann, D. L.: Leucine incorporation as a measure of biomass production by heterotrophic bacteria, in: Handbook of Methods in Aquatic Microbial Ecology, Chap. 58, 509-518, 1993.

Kirchmann, D. L.: Measuring bacterial biomass production and growth rates from Leucine incorporation in natural aquatic environments in: Methods in Microbiology, Chap. 12, 227-237, 2001.

Leppäranta, M. and Manninen, T.: The brine and gas content of sea ice with attention to low salinities and high temperatures, Finnish Institute of Marine Research, Helsinki, Finland, Internal Report, 1988-2, 15 pp., 1988.

Loose, B., McGillis, W. R., Perovich, D., Zappa, C. J., and Schlosser, P.: A parameter model of gas exchange for the seasonal sea ice zone, Ocean Sci., 10, 17-28, doi:10.5194/os-10-172014, 2014.

MacGilchrist, G. A., Garabato, A. C. N., Tsubouchi, T., Bacon, S., Torres-Valdes, S., and Azetsu-Scott, K.: The Arctic Ocean carbon sink, Deep-Sea Res. Pt. I, 86, 39-55, 2014.

Marion, G. M.: Carbonate mineral solubility at low temperatures in the Na-K-Mg-Ca-H-Cl-SO $4-\mathrm{OH}-\mathrm{HCO}_{3}-\mathrm{CO}_{3}-\mathrm{CO}_{2}-\mathrm{H}_{2} \mathrm{O}$ system, Geochim. Cosmochim. Ac., 65, 1883-1896, 2001.

Miller, L. A., Papakyriakou, T., Collins, R. E., Deming, J., Ehn, J., Macdonald, R. W., Mucci, A., Owens, O., Raudsepp, M., and Sutherland, N.: Carbon dynamics in sea ice: A winter flux time series, J. Geophys. Res., 116, C02028, doi:10.1029/2009JC006058, 2011.

Nomura, D., Eicken, H., Gradinger, R., and Shirasawa, K.: Rapid physically driven inversion of the air-sea ice $\mathrm{CO}_{2}$ flux in the seasonal landfast ice off Barrow, Alaska after onset surface melt, Cont. Shelf Res., 30, 1998-2004, 2010.

Nomura, D., Granskog, M. A., Assmy, P., Simizu, D., and Hashida, G.: Arctic and Antarctic sea ice acts as a sink for atmospheric $\mathrm{CO}_{2}$ during periods of snowmelt and surface flooding, J. Geophys. Res.-Oceans, 118, 6511-6524, doi:10.1002/2013JC009048, 2013.

Papadimitriou, S., Kennedy, H., Kattner, G., Dieckmann, G. S., and Thomas, D. N.: Experimental evidence for carbonate precipitation and $\mathrm{CO}_{2}$ degassing during sea ice formation, Geochim. Cosmochim Ac., 68, 1749-1761, 2004.
Papakyriakou, T. and Miller, L.: Springtime $\mathrm{CO}_{2}$ exchange over seasonal sea ice in the Canadian Arctic Archipelago, Ann. Glaciol., 52, 215-224, doi:10.3189/172756411795931534, 2011.

Parmentier, F.-J. W., Christensen, T. R., Sørensen, L. L., Rysgaard, S., McGuire, A. D., Miller, P. A., and Walker, D. A.: The impact of lower sea-ice extent on Arctic greenhouse-gas exchange, Nature Climate Change, 3, 195-202, doi:10.1038/nclimate1784, 2013.

Parsons, T. R., Maita, Y., and Lali, C. M.: A Manual of Chemical and Biological Methods for Seawater Analysis, Pergamon Press, Toronto, 1984

Pierrot, D., Lewis, E., and Wallace, D. W. R.: MS Excel Program Developed for $\mathrm{CO}_{2}$ System Calculations, Carbon Dioxide Information Analysis Center, Oak Ridge National Laboratory, U.S. Department of Energy, Oak Ridge, Tennessee, doi:10.3334/CDIAC/otg.CO2SYS_XLS_CDIAC105a, 2006.

Popova, E. E., Yool, A., Aksenov, Y., Coward, A. C., and Anderson, T. R.: Regional variability of acidification in the Arctic: a sea of contrasts, Biogeosciences, 11, 293-308, doi:10.5194/bg-11-2932014, 2014.

Rysgaard, S., Glud, R. N., Sejr, M. K., Bendtsen, J., and Christensen, P. B.: Inorganic carbon transport during sea ice growth and decay: A carbon pump in polar seas, J. Geophys. Res., 112, C03016, doi:10.1029/2006JC003572, 2007.

Rysgaard, S., Bendtsen, J., Pedersen, L. T., Ramlov, H., and Glud, R. N.: Increased $\mathrm{CO}_{2}$ uptake due to sea ice growth and decay in the Nordic Seas, J. Geophys. Res., 114, C09011, doi:10.1029/2008JC005088, 2009.

Rysgaard, S., Søgaard, D. H., Cooper, M., Pucko, M., Lennert, K., Papakyriakou, T. N., Wang, F., Geilfus, N. X., Glud, R. N., Ehn, J., McGinnis, D. F., Attard, K., Sievers, J., Deming, J. W., and Barber, D.: Ikaite crystal distribution in winter sea ice and implications for $\mathrm{CO}_{2}$ system dynamics, The Cryosphere, 7, 707-718, doi:10.5194/tc-7-707-2013, 2013.

Rysgaard, S., Wang, F., Galley, R. J., Grimm, R., Notz, D., Lemes, M., Geilfus, N.-X., Chaulk, A., Hare, A. A., Crabeck, O., Else, B. G. T., Campbell, K., Sørensen, L. L., Sievers, J., and Papakyriakou, T.: Temporal dynamics of ikaite in experimental sea ice, The Cryosphere, 8, 1469-1478, doi:10.5194/tc-8-14692014, 2014.

Sabine, C. L., Feely, R. A., Gruber, N., Key, R. M., Lee, K., Bullister, J. L., Wanninkhof, R., Wong, C. S., Wallace, D. W. R., Tilbrook, B., Millero, F. J., Peng, T. H., Kozyr, A., Ono, T., and Rios, A. F.: The oceanic sink for anthropogenic $\mathrm{CO}_{2}$, Science, 305, 367-371, 2004.

Sejr, M. K., Krause-Jensen, D., Rysgaard, S., Sorensen, L. L., Christensen, P. B., and Glud, R. N.: Air-sea flux of $\mathrm{CO}_{2}$ in arctic coastal waters influenced by glacial melt water and sea ice, Tellus B, 63, 815-822, 2011.

Semiletov, I. P., Makshtas, A., Akasofu, S. I., and Andreas, E. L.: Atmospheric $\mathrm{CO}_{2}$ balance: The role of Arctic sea ice, Geophys. Res. Lett., 31, L05121, doi:10.1029/2003GL017996, 2004.

Søgaard, D. H., Thomas, D. N, Rysgaard, S., Norman, L., Kaartokallio, H., Juul-Pedersen T., Glud, R. N., and Geilfus, N. X.: The relative contributions of biological and abiotic processes to the carbon dynamics in subarctic sea ice, Polar Biol., 36, 17611777, doi:10.1007/s00300-013-1396-3, 2013. 
Yamamoto, A., Kawamiya, M., Ishida, A., Yamanaka, Y., and Watanabe, S.: Impact of rapid sea-ice reduction in the Arctic Ocean on the rate of ocean acidification, Biogeosciences, 9, 2365-2375, doi:10.5194/bg-9-2365-2012, 2012.

Yamamoto-Kawai, M., McLaughlin, F. A., Carmack, E. C., Nishino, S., and Shimada, K.: Freshwater budget of the Canada Basin, Arctic Ocean, from salinity, $\delta^{18} \mathrm{O}$, and nutrients, J. Geophys. Res.-Oceans, 113, C01007, doi:10.1029/2006JC003858, 2008.
Yamamoto-Kawai, M., McLaughlin, F. A., Carmack, E. C., Nishino, S., and Shimada, K.: Aragonite Undersaturation in the Arctic Ocean: Effects of Ocean Acidification and Sea Ice Melt, Science, 326, 1098-1100, 2009.

Zeebe, R. E. and Wolf-Gladrow, D.: $\mathrm{CO}_{2}$ in Seawater: Equilibrium, Kinetics, Isotopes, Elsevier, Amsterdam, 2001. 